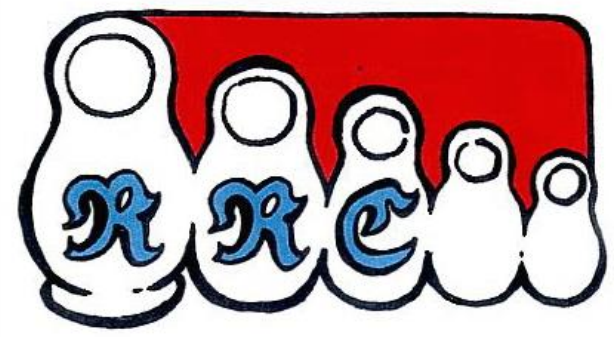

Центр Российских Исследований

RRC Working Paper Series No. 72

Corporate Governance System and Regional Heterogeneity:

Evidence from East and West Russia

Ichiro IWASAKI

November 2017

\author{
RUSSIAN RESEARCH CENTER \\ THE INSTITUTE OF ECONOMIC RESEARCH \\ HITOTSUBASHI UNIVERSITY \\ Kunitachi, Tokyo, JAPAN
}


RRC Working Paper No. 72

November 2017

\title{
Corporate Governance System and Regional Heterogeneity: Evidence from East and West Russia* $^{*}$
}

\section{Ichiro Iwasaki}

\author{
Russian Research Center, Institute of Economic Research \\ Hitotsubashi University \\ 2-1 Naka, Kunitachi City, Tokyo 186-8603, JAPAN \\ TEL.: +81-42-580-8366 / FAX: +81-42-580-8333 \\ E-mail: iiwasaki@ier.hit-u.ac.jp
}

\begin{abstract}
Using a unique firm-level dataset obtained from a large-scale questionnaire survey conducted in late 2015, we examined the generality and heterogeneity of corporate governance systems between the eastern and western regions of Russia. The survey results strongly suggest that various characteristics of corporate governance systems observed in industrial firms and listed companies are, in fact, common and long-term trends that are seen across all Russian business sectors. At the same time, however, we also found pronounced regional heterogeneity between the eastern and western regions, with companies in the east being more reluctant than those in the west to introduce a governance system to monitor and supervise top management. Regression analysis shows that this finding is robust, even after a series of firm-level attributes are simultaneously controlled for.
\end{abstract}

JEL classification numbers: D22; G34; L22; M42; P25; P31

Keywords: corporate governance system; legal form of incorporation; board of directors; audit system; regional heterogeneity; Russia

\footnotetext{
* This research work is a product of the project titled, "Market Quality in the Russian Far East from the Viewpoint of Company Management," sponsored by the Economic Research Institute for Northeast Asia (ERINA), Niigata, Japan, and was financially supported by a grant-in-aid for scientific research from the Ministry of Education, Culture, Sports, Science and Technology of Japan (No. 26245034). I am grateful to Yoshiaki Nishimura, former representative director of ERINA, for his initiative for the project. I also would like to thank project members and participants in the 2nd World Congress of Comparative Economics at the Higher School of Economics in Saint Petersburg, June 15-17, 2017, for their valuable comments and suggestions, as well as Tammy Bicket and Mai Shibata for their editorial assistance.
} 


\section{Introduction}

For the past quarter-century, after the fall of the Soviet Union, Russia has striven to modernize its corporate systems. The progress it has made is nothing short of remarkable. In fact, by the mid-2000s, Russia's corporate law had been improved to incorporate a framework and contents that are comparable to those in developed nations (Oda, 2007). The administrative and judicial institutions that handle the registration and dissolution of companies and mediate business disputes are also fulfilling their functions, to a certain extent. In addition, it is no exaggeration that business service industries that provide accounting audits, management consulting, job placement services, and information communications and data processing services to companies, as well as financial intermediation today are, though still a work in progress, a world away from what they were 25 years ago. Furthermore, in the World Bank's assessment of the ease of doing business, Russia was ranked 40th among the world's 190 countries, as of 2017, which is close to Japan's ranking of 34th and higher than those of several Central and Eastern European EU member states, including Hungary and Croatia (World Bank, 2017). Considering the fact that Russia was ranked as low as 106 of 178 countries in the same ranking a decade ago (World Bank, 2008), it is evident that the environment surrounding Russian firms has improved considerably in recent years.

In this time of rapid change, Russian companies themselves have also evolved to refine their management organizations to adapt to market competition and globalization. A corporate governance system, which provides a framework for effective discipline of management executives to enable the attainment of business objectives and maximization of firm value, is a matter of great interest not only to policymakers and investors in Russia, where the separation of ownership and management is progressing at a fast pace, but also to researchers who have striven to gain deeper insights into the internal organizations of Russian corporations. ${ }^{1}$ Although the quantity of empirical evidence available on Russian companies is fairly limited compared to that available on companies in developed economies, it has produced a common understanding that can be referred to as "stylized facts" about the Russian corporate governance system. This research evidence, however, is not without limitations: First, it is strongly dependent on findings from investigations and analysis of mining and manufacturing sectors and listed companies; therefore, it does not guarantee generality across the whole Russian corporate sectors. Second, although Russia, due to its vast territories, exhibits substantially different socioeconomic systems regionally, to the best of our knowledge, and according to the latest literature review conducted

\footnotetext{
${ }^{1}$ See Iwasaki (2007b) and Puffer and McCarthy (2011), which offer comprehensive literature surveys of corporate governance in Russia.
} 
by Muravyev (2017), ${ }^{2}$ no empirical study has been published to date that addresses the regional heterogeneity in corporate governance systems. Filling these gaps would undoubtedly have significant implications, not only for the study of the Russian economy but also for corporate finance and organizational economics. In this study, to address these two issues, we will elucidate the general structure of the Russian corporate governance system based on firm-level data of listed and unlisted companies encompassing a vast range of industries and verify the presence and degree of regional heterogeneity between the eastern and western regions of Russia.

The empirical analysis presented in this paper is based on a large-scale questionnaire survey conducted by the Economic Research Institute for Northeast Asia (ERINA) during the fourth quarter of 2015 (hereafter referred to as the ERINA Enterprise Survey). During the ERINA Enterprise Survey, a questionnaire was administered by interview in eight regions (i.e., federal entities) in eastern Russia and nine regions in western Russia, and valid responses were obtained from a total of 742 executives from 17 industrial sectors. ${ }^{3}$ According to the Russian Federal State Statistics Service (ROSSTAT), there were a total of 3391 registered business corporations in these 17 regions, encompassing 17 industrial sectors as of the end of 2013, 21.9\% of which were covered in the ERINA Enterprise Survey. The average number of employees across the surveyed companies was 193.8 (median: 80), which is consistent with that of typical medium-scale firms in local areas. The distribution of these companies across industrial sectors suggests that the 742 surveyed firms reflect an excellent representation of various industries in the country. The survey results contain detailed data regarding not only the basic company profile but also the ownership structure, legal form of incorporation, board of directors, and audit committee, as well as the contracted external auditor (audit firm) that enables us to seek our objectives. ${ }^{4}$

The survey results strongly suggest that various characteristics of the Russian corporate governance system identified by previous studies that focused mainly on industrial firms and listed companies are, in fact, common and long-term trends that are seen across all Russian business sectors. At the same time, however, we also found pronounced regional heterogeneity between the eastern and western regions, with companies in the east being more reluctant than those in the west to introduce a governance system to monitor and supervise top management. Regression analysis verified that this finding is robust, even after a series of firm-level attributes are simultaneously controlled for.

\footnotetext{
2 See Section 3 and Appendix A in Muravyev (2017).

${ }^{3}$ Most respondents were either the president or executive director, accounting for $63.2 \%$ of all respondents. The average tenure and age of respondents were 7.6 years (median: 6 years) and 46.3 years (median: 46 years), respectively.

${ }^{4}$ For further details about the ERINA Enterprise Survey, see Arai and Iwasaki (2016).
} 
The reminder of this paper is structured as follows: In the next section, a common understanding among researchers about the structure and problems of the Russian corporate governance system is reviewed, based on the findings presented by previous studies. In Section 3, we examine the results of the ERINA Enterprise Survey in detail by using univariate comparative analysis of the eastern and western regions of Russia. In Section 4, multivariate regression analyses are performed to verify in a more rigorous manner the presence and degree of regional heterogeneity in corporate governance systems. Finally, in Section 5, we summarize the major findings and discuss their policy implications.

\section{Stylized Facts of the Corporate Governance System in Russia: Literature Review}

In this section, we first discuss the legal frameworks of Russian corporate systems and then argue the structure and problems of the Russian corporate governance system that have been identified in previous studies.

Russian law recognizes the following types of profit corporations and profit-seeking organizations as legal entities that can be founded within Russian territory: unitary enterprises, ${ }^{5}$ business partnerships (general partnerships, limited partnership companies), business companies (limited liability companies, supplementary liability companies, commercial companies, jointstock companies), and production cooperatives. According to the official statistics shown in Table 1, as of January 2016, when the ERINA Enterprise Survey had just ended, business partnerships/companies except joint-stock companies (JSCs) accounted for $95.1 \%$ of all profit organizations, most of which fall under the category of limited liability companies (LLCs). In contrast, JSCs accounted for only 3.0\%. However, taking into consideration the fact that the majority of state-owned enterprises were privatized by conversion into JSCs in the 1990s, just as many medium- and large-scale companies are run as JSCs as those that are run as LLCs (Iwasaki, 2014a). This is precisely the reason why researchers investigating and analyzing corporate governance systems in Russia have focused their attention first on JSCs, and then on LLCs.

Table 2 shows the statutory company organs within LLCs and JSCs in Russia. As described in this table, although these two legal forms of incorporation differ from one another in terms of which statutory company organs are mandatory, conditional, or optional, the board of directors (also referred to as the "supervisory board") and the audit committee (auditor) are defined for both corporate organs as the internal organizations responsible for monitoring and supervising management. Furthermore, the Federal Law of Audit Activities requires that JSCs, securities

\footnotetext{
${ }^{5}$ Unitary enterprises refer to those purely state-owned and municipally owned enterprises that are exclusively owned by state institutions.
} 
distribution companies, financial institutions, and any profit organizations whose annual sales or asset balance exceeds a designated amount shall be audited by an external certified auditor or audit firm. ${ }^{6}$ The mandatory external audit requirements are relatively stringent, and most LLCs are also required to be audited by an external entity. In view of these facts, focusing attention not only on the board of directors and the audit committee but also on the auditors and audit firms selected by the companies to conduct these external audits is key to understanding the fundamental structure of the Russian corporate governance system. ${ }^{7}$

Because the study of corporate governance in Russia was initially motivated by the privatization of state-owned companies, the overwhelming majority of the literature related to the internal organization of Russian firms is focused on ownership structure, with many such studies, in fact, being published in recent years (Ankudinov and Lebedev, 2016; Liljeblom and Maury, 2016; Moser, 2016). Since the late 1990s, however, a group of researchers, such as Blasi and Shleifer (1996), Wright et al. (1998), and Filatotchev et al. (1999a, 1999b), have published a number of articles in which they addressed the size and composition of boards of directors. From the same viewpoint, some notable research articles also published in the 2000 s include those by Bevan et al. (2001), Judge et al. (2003), and Peng et al. (2003). The latest studies on listed companies are represented by Muravyev et al. (2014) and the aforementioned Muravyev (2017). ${ }^{8}$

In addition to these extant studies, findings produced by a joint research project undertaken by the Institute of Industrial and Market Research of Higher School of Economics (HSE) and the Institute of Economic Research of Hitotsubashi University (HU) also contributed to improving our understanding of the Russian system of corporate governance (Dolgopyatova et al., 2009). The study carried out in this research project is based on a large-scale questionnaire survey carried out across the Russian Federation during the first half of 2005 that was administered to both listed and unlisted JSCs in the mining, manufacturing, and telecommunications sectors (Dolgopyatova and Iwasaki, 2006); furthermore, the project examined not only boards of directors, but also

\footnotetext{
${ }^{6}$ According to the Federal Law of Audit Activities that was in effect at the time this paper was written, any profit organization with annual sales of at least 400 million rubles and/or an asset balance of at least 60 million rubles is required to be audited by an external entity (Art. 5, Para. 4).

7 The single executive body refers to a top manager (CEO, President, or General Director), while the collective executive board consists of corporate officers and executes company management in cooperation with the single executive body. For more details of the legal forms of incorporation and statutory company organs of Russian companies, see Dolgopyatova et al. (2009) and Iwasaki (2007a; 2008; 2013).

${ }^{8}$ Quite a few articles have been published in Russian as well as international comparative studies that include Russia, which we will not mention here because they have already been cited by Muravyev (2017).
} 
corporate forms and audit systems, for which very little evidence is currently available in the literature. These characteristics make the HSE-HU joint research project an adequate candidate for comparison with the ERINA Enterprise Survey.

The major findings on corporate governance systems produced by the HSE-HU joint project can be summarized as follows:

(a) Legal form of incorporation: Most JSCs in Russia, including medium- and large-scale companies, are run as private (closed) rather than public (open) companies. This is mainly due to factors such as significant inside ownership, a strong orientation among managers toward closed organizations, slumping needs for corporate finance, and weak local financial institutions.

(b) Board of directors: (1) With the exception of companies with an extremely small number of shareholders with voting rights, most JSCs have a board of directors. (2) The corporate board consists of an average of 6.6 directors (median: 7), with an average of $48.9 \%$ (median: $55.6 \%$ ) of them being elected from outside the company. The surveyed firms, however, were actually split between two extremes: those with more than $80 \%$ of board directors elected from outside the company and those with no more than $10 \%$ outside directors. (3) Few companies employ independent directors; consequently, independent directors account for only $6.5 \%$ of all board directors. ${ }^{9}$ (4) Board chairmen are most often appointed from inside the company (45.9\%), followed by $30.9 \%$ who are appointed from outside the company and $23.2 \%$ who are invited from an affiliated business group or close business partner. (5) While the bargaining balance between the management and outside shareholders is a strong determinant of a board's composition (Hermalin and Weisbach, 1998), factors such as the historical background of the company's foundation, board size, export performance, debt ratio, and intensity of research and development (R\&D) activities can also have a certain influence on the board structure.

(c) Audit system: (1) The audit committee consists of an average of 3.5 corporate auditors (median: 3 ), with an average of $42.8 \%$ (median 33.0\%) being appointed from outside the company. Just as in the case with boards of directors, the surveyed firms were split between two extremes: those with more than $90 \%$ of auditors elected from outside the company and those with no more than $10 \%$ outside auditors. (2) Expert auditors account for only $16.5 \%$ of all committee members, and the majority of companies employ no expert auditors at all. (3) Local small- and mediumsized audit firms account for $68.5 \%$ of all external auditors elected by surveyed companies, and

\footnotetext{
9 According to Muravyev et al. (2014) and Muravyev (2017), the board of directors of Russian listed companies consists of 8.8 members on average, with $57 \%$ elected from outside the company and $10 \%$ independent directors. Furthermore, the polarization in board composition in terms of the proportion of outside directors observed by Iwasaki (2008) was not so marked in listed companies investigated by these authors.
} 
large-scale national audit firms and international audit firms account for only $23.2 \%$ and $8.3 \%$, respectively. (4) The independence and expertise of the audit system in a company are strongly and positively correlated with the proportion of outside directors on the board (Iwasaki, 2008, 2014a, 2014b; Dolgopyatova et al., 2009).

In addition, a follow-up survey conducted during the fourth quarter of 2009 by a team of Japanese researchers also revealed that changes in ownership structures and corporate governance systems were occurring at a very slow pace, and that no significant structural changes were observed in either boards of directors or audit systems in Russian industrial companies during the period from 2005 to 2009 (Iwasaki, 2016).

The findings and empirical evidence obtained from the HSE-HU joint project and its followup survey are more or less in agreement with those from other previous studies. In sum, the existing literature generally addresses stylized facts about the structure and problems of the Russian corporate governance system, and the empirical findings presented by Iwasaki (2016) strongly suggest that the internal organizations of Russian firms today are highly likely to have structural features that resemble those identified by previous studies.

\section{Survey Results}

In this section, we report results of the ERINA Enterprise Survey and, based on them, perform univariate analysis to tackle the following two questions: Can the stylized facts about the Russian corporate governance system described in the previous section be observed in the 742 companies included in the ERINA Enterprise Survey? Is there significant regional heterogeneity between the eastern and western regions of Russia with respect to corporate governance systems? To this end, the next three subsections examine the survey results regarding the legal form of incorporation, the board of directors, and the audit system. The fourth subsection draws the overall structure of corporate governance systems in the surveyed firms and argues the differences between the eastern and western regions from this perspective.

\subsection{Legal Form of Incorporation}

The legal forms of incorporation of the 742 surveyed firms are shown in Table 3. As described in Section 2, although various types of profit organizations can be established under Russian law, only JSCs and LLCs were included in the ERINA Enterprise Survey. Accordingly, the 742 surveyed firms fall under one of the following three categories: public JSCs (referred to as open JSCs in the former law), private JSCs (closed JSCs), and LLCs.

According to Table 3, 550 (74.1\%) of 742 surveyed firms are run as LLCs. The remaining 192 companies $(25.9 \%)$ are operating as JSCs. The percentage of JSCs in the surveyed firms is 
much higher than that shown by the official statistics in Table 2. This is probably attributable to the fact that the ERINA Enterprise Survey only targeted companies with an annual average number of employees of 50 or greater. Nevertheless, even among medium- and large-scale companies in Russia, the overwhelming majority are operated as LLCs.

A chi-square test of equality detects a difference in the proportions of corporate forms between the eastern and western regions at the $5 \%$ level of statistical significance (Chi2 $=7.8013$, $p=0.0202$ ). This difference, however, is caused, not by the difference in the percentage shares of LLCs, but rather by the differences in the shares of public JSCs and private JSCs, as indicated in

Table 3. While the shares of JSCs are more or less the same between the two regions ( $24.9 \% \mathrm{vs}$. $26.8 \%$ ), the share of public JSCs is approximately $20 \%$ lower in the west than in the east $(70.8 \%$ vs. $51.5 \%$ ), with the difference being highly significant according to a $z$-test of proportions $(z=2.731, p=0.0063)$. To sum up, although no marked difference is observed between eastern and western companies with respect to the choice of LLC or JSC, considerably more JSCs in the east than their counterparts in the west are likely to opt for a more open organizational architecture as their legal form of incorporation. This finding is closely related to the survey results with respect to board of directors and audit system, as described in the following subsections.

\subsection{Board of Directors}

Table 4 shows the survey results regarding the establishment, membership size, and composition of the board of directors.

As shown in Panel (a) of Table 4, the board of directors of 212 (28.6\%) of 742 surveyed companies plays a key role in corporate governance. This implies that three of four Russian companies do not have a statutory company organ responsible for monitoring and supervising top management. This disappointing situation may reflect a lack of understanding about the need for corporate governance on the part of local governments and stakeholders. Furthermore, the same panel also shows that this trend is more prominent in the eastern region than in the western region. In fact, the percentage of surveyed firms that do not establish a board of directors is $68.2 \%$ (262 of 384 ) in the west and $74.9 \%$ ( 268 of 358 ) in the east. The difference between the two regions is significant at the $5 \%$ level $(z=-1.998, p=0.0457)$.

However, when the focus is shifted to only those companies with a corporate board, new facts reveal themselves: First, according to Panel (b) of Table 4, which displays the frequency distribution of the board size, while a board typically consists of three to seven directors in both the eastern and western regions, eastern companies are more likely than their western counterparts to appoint a large number of directors to discipline the company's management. In fact, the mean number of board directors is 4.5 (median: 4.5) for companies in the west and 5.3 (median: 5.0) 
for companies in the east; this difference between the two regions is statistically significant at the $5 \%$ level in both the $t$-test of means and the Wilcoxon (Mann-Whitney) rank sum test ( $t=2.4734$, $p=0.0142$; Wilcoxon $z=2.332, p=0.0197$ ).

Second, there are noteworthy differences between eastern and western companies in board director attributes. Panel (c) of Table 4 shows that the 212 surveyed companies have a total of 1027 directors on their boards. Among them, inside directors, which consist of managers and/or representatives of employees and labor unions, account for $54.9 \%$, whereas outside directors, which consist of independent directors and representatives dispatched from government agencies and/or non-employee private shareholders, account for $45.1 \%$. A test of equality carried out by using the seven categories of board directors ranging from management representatives to other outside members reveals highly significant differences between the eastern and western regions (Chi2 $=97.3559, p=0.0000$ ), with the value of Cramer's coefficient of association being very high $(V=0.3078)$. As a result, the proportion of outside directors in the west becomes much lower in the east (37.2\% vs. $54.2 \%)$, and this difference is also highly significant $(z=5.4590, p=0.0000)$. In other words, despite the fact that eastern companies seem more reluctant than their western counterparts to establish a board of directors, the corporate boards in eastern companies tend to be greater in size and accept a greater number of members from outside the company. This finding closely corresponds with the differences observed between the eastern and western regions with respect to the choice of corporate form discussed in the previous subsection.

Intraregional differences in board composition are just as important as interregional differences for grasping the reality of Russian corporate governance. Figure 1 illustrates the distribution of 212 surveyed firms with corporate boards in terms of the proportion of outside directors. The mean (median) share of outside directors is $41.7 \%$ (33.3\%) when all 212 companies are taken into consideration. The figures for western and eastern companies are $36.5 \%(33.3 \%)$ and $48.6 \%(50.0 \%)$, respectively. The differences between the two regions are significant at the $5 \%$ level in both the $t$-test and the Wilcoxon rank sum test $(t=2.2782, p=0.0237$; Wilcoxon $z=2.029, p=0.0424)$. What is noteworthy here is the fact that only a very limited number of surveyed firms are actually at the statistical mean or close to it in both regions. In other words, they are, in fact, split between two extremes: those that have few or no outside directors and those whose corporate board consists almost entirely of outsiders. No difference is found between the east and west with respect to this polarization tendency of board composition, with a test of equality showing an insignificant result $(\mathrm{Chi} 2=13.5562, p=0.1390)$. Furthermore, according to Figure 2, the mean percentage of independent directors is 8.3\% (median: $0.0 \%$ ) among the 212 companies with a board. It is extremely low, and no significant difference is observed between the two regions in this respect. Thus, findings from the ERINA Enterprise Survey strongly support 
the stylized facts presented by previous studies that most Russian companies either have very few board directors elected from outside the company or have a board consisting almost entirely of outsiders, and that Russian firms are generally reluctant to appoint independent directors.

Another important aspect concerning the board composition in Russia firms is the appointment route of the chairman of the board. The related survey results are reported in Table 5. As this table shows, of the chairmen of the board of 194 companies that provided valid responses, 140 are insiders or quasi-insiders who have been promoted from inside the company or invited from an affiliated business group or a business partner, whereas only 54 are outsider chairmen who have been elected from government agencies, parliaments, or other companies. As a result, insider and quasi-insiders account for $72.2 \%$ of all board chairmen. Although a test of equality carried out by using the six categories of board chairmen detects a significant difference between the eastern and western regions at the $5 \%$ level (Chi2 $=11.8723, p=0.0365$ ), a comparison with respect to the percentage of board chairmen who fall under the category of insiders or quasiinsiders yields an insignificant result $(z=0.232, p=0.8162$ ). These findings suggest that, regardless of the company's location, board chairmen elected by a majority of Russian firms often share interests with the executive officers. This observation is also well in line with the stylized facts with respect to the board structure in Russian firms described in Section 2.

\subsection{Audit System}

Table 6 shows the survey results with respect to the establishment, membership size, and composition of the audit committee. As reported in Panel (a) of this table, only 244 (34.1\%) of 715 surveyed firms that provided valid responses have an audit committee, suggesting a lack of understanding about the importance of internal control over financial reporting in local areas of Russia. As is the case with a board of directors, the percentage of companies that adopt an audit committee is approximately $7 \%$ lower in the eastern region than in the western region $(30.5 \% \mathrm{vs}$. $37.4 \%)$. A test of proportions confirms that this difference between the two regions is significant at the $10 \%$ level $(z=-1.9504, p=0.0511)$.

According to Panel (b) of Table 6, 115 (47.1\%) of 244 companies organize their audit committees with three corporate auditors. This is followed by 37 (15.2\%) companies having a committee consisting of five members. This trend is common in both the east and west, and no significant difference can be found in any statistical tests.

There are, however, notable gaps between the two regions with respect to auditor attributes. Panel (c) of Table 6 shows that a total of 904 corporate auditors can be identified from the 224 surveyed firms with an audit committee. Among them, inside auditors, managers and/or representatives of employees and labor unions, account for $66.5 \%$, while outside auditors that 
include representatives of government agencies and/or non-employee private shareholders and expert auditors account for only 33.5\%. Although inside auditors form the majority in both regions, their percentage share is much lower in the east than in the west (55.5\% vs. $74.0 \%)$, with the difference being highly statistically significant $(z=-5.7881, p=0.0000)$. This result can be explained by the fact that while western companies are inclined to actively invite representatives of employees and labor unions to join the audit committee, their eastern counterparts tend to elect corporate auditors with various backgrounds from outside the company.

Consequently, the presence of outsiders in the audit committee at the firm level also varies greatly between the east and west. In fact, the mean (median) percentage of outside auditors in western companies is approximately $20 \%(30 \%)$ lower than that in their eastern counterparts $(24.5 \%(0.0 \%)$ vs. $45.1 \%(33.3 \%))$. This difference is highly significant based on both the $t$-test and the rank sum test $(t=4.2160, p=0.0000$; Wilcoxon $z=3.543, p=0.0004)$. This finding, however, does not imply that the polarization tendency, where most companies are split between those that have few or no outside auditors and those whose audit committee consists almost entirely of outsiders, varies greatly between the east and west. On the contrary, as distinctly exhibited in Figure 3, this phenomenon is evident in both regions. At the same time, as shown in Figure 4, in eastern and western regions alike, very few companies appoint expert auditors.

As reported in Panel (a) of Table 7, a total of 710 surveyed firms provided valid responses concerning external audit activities. This reveals that 312 (43.9\%) of the 710 companies execute external audits, and there is no statistically significant difference between eastern and western regions in this respect $(z=-0.9595, p=0.3373)$. Panel (b) of the same table shows, however, that remarkable differences can be found between the two regions with respect to the types of external auditors the surveyed firms contract with. Although both eastern and western companies are strongly inclined to select local individual auditors or indigenous audit firms to conduct an external audit, the percentage of companies that contract with local entities is $18 \%$ lower in the east than in the west $(65.7 \%$ vs. $83.7 \%)$, with the difference being highly significant $(z=-3.6853$, $p=0.0002$ ). Considering the geographical constraints faced by firms in these two regions, eastern companies are more likely than their western counterparts to encounter difficulties in using international audit firms or large-scale audit firms as their external auditor in terms of time and costs. It is noteworthy, however, that companies in the east are more inclined than those in the west to seek audit firms capable of providing higher quality external auditing.

\subsection{Generality and Heterogeneity of Corporate Governance Systems across Russian Regions}


The observations made in this section can be summarized as follows: (1) Among Russian companies, the LLC by far outnumbers the JSC as a legal form of incorporation. On the other hand, the number of private JSCs almost equals the number of public JSCs. However, JSCs in the eastern region are slightly more likely than those in the western region to be run as public companies. (2) Only a limited number of Russian firms have boards of directors and/or audit committees and, thus, adopt a legitimate corporate governance system. This trend is more notable in the east than in the west. (3) Although, in both regions, a board of directors typically consists of three to seven members, companies in the east tend to have slightly larger corporate boards than their counterparts in the west. (4) Corporate boards in eastern companies operate with a greater degree of outside directorship as compared to their western counterparts. At the same time, however, the percentage share of independent directors is extremely low in both the east and west. (5) The percentage of board chairmen elected from outside the company is less than $30 \%$ in both regions. (6) Typical audit committees consist of three auditors, and no statistically significant difference is observed between the two regions, in this respect. (7) The presence of outside auditors in the audit committee is much larger for companies in the east, as compared to their counterparts in the west. On the other hand, the percentage share of expert auditors is extremely low in both regions. (8) The polarization tendency seen in the degree of independence of a board of directors and/or an audit committee from the management was evident and common in both regions. (9) The percentage of surveyed firms performing external auditing is a little over $40 \%$ in both the east and west, with no statistically significant difference found between the two regions. (10) Irrespective of a company's location, Russian firms are strongly inclined to select local individual auditors and indigenous audit firms as their external auditors. Eastern companies, however, are more likely than their western counterparts to select audit firms with greater levels of independence and expertise to conduct their external auditing.

The above findings demonstrate that the stylized facts about the Russian corporate governance system obtained from observations of industrial firms and listed companies are mostly true for the organization of companies studied in the ERINA Enterprise Survey. They also strongly indicate that the so-called "corporate governance syndrome" in Russia is a common, lasting condition that affects all types of Russian firms regardless of in which industrial sector they operate. This section has also manifested that there is no fundamental gap between the eastern and western regions of Russia with respect to the severity of this problem.

At the same time, from the perspective of regional heterogeneity in the Russian corporate governance system, the findings obtained from the ERINA Enterprise Survey also strongly point to the possibility that there could be considerable differences between the eastern and western regions of Russia. However, the simple aggregation of survey results or univariate analysis based 
on such aggregate data cannot address how the heterogeneity across surveyed companies resulting from differences in industrial sectors, company's history of establishment, ownership structure, firm organizations, management activities, and other factors may affect survey results. In other words, to more closely examine the presence of regional heterogeneity in the corporate governance systems in Russia, it is necessary to validate whether statistically significant differences can be detected between the two regions even after simultaneously controlling for a series of factors that may influence the structure of corporate governance systems in surveyed firms. This is exactly what the next section will deal with.

\section{Regression Analysis}

In order to answer the aforementioned question, in this section, we attempt to verify the presence of regional heterogeneity by performing multivariate regression analysis. More concretely, we estimate the following regression equation, taking the probability of selecting a specific corporate form, the probability of establishing a board of directors, board composition, the probability of adopting an audit committee, the audit committee's structure, the probability of executing an external audit, and attributes of the external auditor as dependent variables and a dummy variable that assigns a value of 1 to firms operating in the eastern region of Russia (EAST) as an independent variable:

$$
y=\mu+\beta_{1} E A S T+\sum_{i=2}^{n} \beta_{i} x_{i}+\varepsilon,
$$

where $y$ is a dependent variable, $\mu$ is a constant term (intercept), $x$ is a control variable $\left(x_{2}, \ldots, x_{\mathrm{n}}\right)$, $\varepsilon$ is an error term, and $\beta$ is a parameter to be estimated. The presence of regional heterogeneity is examined by testing the null hypothesis that $\beta_{1}$ is zero.

\subsection{Variable Selection and Estimation Method}

In light of the discussion in the previous section, the following dependent variables $(y)$ are introduced in the left-hand side of the corporate form choice model: an ordinal variable that gives a larger value to firms having a greater degree of organizational openness from the viewpoint of the legal form of incorporation (CORFOR) and two dummy variables that specify public (open) JSCs and private (closed) JSCs by 1, respectively (PUBJSC, PRIJSC). To examine regional heterogeneity in the probability of establishing a board of directors, we utilize a dummy variable for companies having a board of directors (BODFIR). With respect to the board's composition, we use four variables, including the total number of board directors (NUMDIR), the proportion of outside directors $(B O A C O M)$, the proportion of independent directors (INDDIR), and the outsideness of the board chairman (BOALEA). Similarly, in the audit system model, the following 
six variables are introduced as dependent variables: a dummy variable for firms with an audit committee (AUDFIR), the total number of audit committee members (NUMAUD), the proportion of outside auditors ( $A U D C O M$ ), the proportion of expert auditors ( $A U D E X P)$, a dummy variable for companies that carry out external audits (EXTAUDFIR), and an ordinal variable that expresses the level of independence and expertise of the contracted external auditor (EXTAUD).

A total of 28 variables described below are adopted as control variables $(x)$ : In reference to Iwasaki (2014a), to examine possible regional heterogeneity in the choice of corporate form, the probability of establishing a board of directors and an audit committee, and the probability of executing an external audit, we estimate the $E A S T$ variable simultaneously with four variables representing the ownership structure consisting of outside ownership share $\left(\right.$ OWNOUT), ${ }^{10}$ a dummy for state-owned and municipal companies $(S T A O W N)$, a dummy for foreign-owned firms $(F O R O W N$ ), and large managerial shareholder dummy (MANSHA), as well as a business group affiliation dummy (GROFIR), a dummy for former state-owned or ex-municipal privatized companies (PRIVAT), and a dummy variable for firms spun off from a state-owned/ex-municipal company or privatized company (SPIOFF), which captures the path-dependent effect exerted by the process of establishing a company, a dummy variable for firms located in urban areas $(U R B A N)$ to control for the heterogeneity of companies' locations between urban and rural areas, a natural logarithm of the average annual number of employees (COMSIZ), which serves as a proxy for company size, and a group of industry dummies to control for industry-level fixed effects. $^{11}$

Furthermore, following the procedure of Iwasaki (2008), for estimating the corporate board model, the following variables are simultaneously estimated along with the nine control variables mentioned above: two dummy variables for corporate forms of JSC (PUBJSC, PRIJSC), the share of exports in total sales (EXPSHA), the use of bank credits and their average lending period $(B A N C R E)$, and research and development expenses $(R \& D)$. On the other hand, in the audit system model, we introduce the proportion of outside directors (BOACOM) instead of the ownership variables of OWNOUT and MANSHA to account for the fact that a board of directors

\footnotetext{
10 The ownership share of domestic individual shareholders is excluded from the OWNOUT variable so as to exclude the inside ownership effect exerted by the family members, relatives, or friends of management executives and employees, all of whom formally fall under the category of outside shareholders.

11 These include a total of 13 industrial sectors, consisting of mining, food industry, light industry, wood and paper products, chemical and petrochemical, building materials, metallurgy, machinebuilding, electricity, gas and water supply, construction, wholesale trade, transport, and telecommunications. The default category is agriculture, forestry, and fisheries industries.
} 
can directly and decisively determine the structure of a company's audit system, which is strongly backed up by empirical analysis in Iwasaki (2014b).

For estimating the regression models above, the probit, ordered probit, Poisson, and Tobit estimators are applied, respectively, to the following types of dependent variables: binary random variables (BODFIR, AUDFIR, EXTAUDFIR), ordinal variables (CORFOR, BOALEA, EXTAUD), count data (NUMDIR, NUMAUD), and truncated data (BOACOM, INDDIR, AUDCOM, $A U D E X P)$. For estimating a model that involves selection from three types of corporate forms, namely LLC, private JSC, and public JSC, the multinomial probit estimator is employed.

When analyzing the composition of the corporate board and audit committee as well as the attributes of the external auditor, it is necessary to take into account the fact that, as reported in the previous section, many companies do not adopt these company organs and/or do not perform external auditing at all. This is because, if the probability of establishing a company organ or performing an external audit is expressed as $y_{\text {prob }}$, and the composition of company organs or the attributes of an external auditor as $y_{\text {attr }}, y_{\text {attr }}$ can only be observed in companies that establish these organs inside or contract with an external auditor. For this reason, a regression model that uses these dependent variables can be expressed as follows:

$$
f\left(y_{a t t r}\right)=\left\{\begin{array}{ll}
0 & \text { if } y_{\text {prob }}=0 \\
\mu+\beta_{1} E A S T+\sum_{i=2}^{n} \beta_{i} x_{i}+\varepsilon & \text { if } y_{\text {prob }}=1
\end{array} .\right.
$$

Estimating Equation (2), using an ordinary least squares (OLS) estimator, may produce inconsistent estimates due to sample selection bias, a problem that is highly likely to be exacerbated with increasing numbers of samples in which $y_{\text {attr }}$ cannot be observed (Greene, 2017). To address this issue, we estimate a Heckman two-step selection model that controls for selection bias by using the inverse Mills ratio, ${ }^{12}$ in addition to a regression model that utilizes only observations of companies that adopt a company organ in question or carry out an external audit for a robustness check.

Table 8 lists the definition and descriptive statistics of the variables used in the estimation of Equations (1) and (2). ${ }^{13}$

\footnotetext{
12 The inverse Mills ratio is the ratio of the probability density function to the cumulative distribution function of a distribution and can be used to correct for the selection bias caused by truncated data. In the Heckman two-step estimation, the inverse Mills ratio is generated in the first-stage estimation and introduced into the right-hand side of the regression equation in the second-stage estimation.

${ }^{13}$ Excluding industry dummies. In addition to Table 8, the Appendix in this paper reports descriptive statistics of the variables by region and the results of univariate comparative analysis between the eastern and western regions.
} 


\subsection{Estimation Results}

Tables 9, 10, and 11 show estimation results. In these tables, heteroscedasticity-consistent standard errors are reported in parentheses beneath the regression coefficients. Standard errors for the Heckman two-step selection model are estimated by using the bootstrapping method.

Estimation results of the corporate form choice models in Table 9 show that, when the ownership structure, business group affiliation, company's history of establishment, location in an urban area, and company size are simultaneously controlled for, there is no statistically significant difference between the eastern and western regions with respect to the openness of the legal form of incorporation. In fact, Model [1] in this table does not reject the null hypothesis that the regression coefficient $\left(\beta_{1}\right)$ for $E A S T$ is zero. On the other hand, the regression equation that uses PRIJSC as the dependent variable in the multinomial probit model [2] yields a negative estimate for $E A S T$ at the $5 \%$ significance level, which means that, all other conditions being equal, the probability of companies in the east selecting private (closed) JSC as their corporate form is $51.8 \%$ lower than that of companies in the west.

In Table 10, which shows the estimation results of the corporate board models, Model [1] shows that companies in the east are more reluctant to establish a board of directors than their counterparts in the west, even when a series of firm-level attributes are taken into account. Actually, eastern firms have a $26.7 \%$ lower probability of establishing a corporate board than their western counterparts do. This result possibly reflects a lack of understanding regarding the necessity of a corporate governance system on the part of the company executives and investors in Russia's eastern region. With regard to board composition, Model [2] in the same table suggests that companies in the east have on average 0.095 more board directors than companies in the west do. This result, however, is not supported by a Heckman two-step model [3] that adjusted for potential selection bias. As shown in Models [4] and [5], when other corporate attributes are considered, no significant difference is found between the east and west with respect to the proportion of outside directors. Based on the estimation results from Models [8] and [9], a similar conclusion can be drawn about the outsideness of board chairmen. On the other hand, Models [6] and [7] indicate that, on average, eastern firms have a lower percentage share of independent directors than western firms do. This difference between the two regions, however, becomes considerably smaller when the sample selection bias is adjusted for.

The estimation results of the audit system models in Table $\mathbf{1 1}$ also point to a similar regional difference to that observed in the corporate board models. Namely, all other conditions being equal, companies in the east have a $36.0 \%$ lower probability of establishing an audit committee than do their counterparts in the west. Similarly, eastern firms have a $26.3 \%$ lower probability of 
executing external audits than do western firms. However, from the perspectives of the structure of the audit committee and the attributes of the external auditor, heterogeneity between the eastern and western regions does not exert a significant influence on these factors when simultaneously controlling for other firm-level attributes and the sample selection bias. ${ }^{14}$

\section{Conclusions}

Based on the results obtained from a large-scale questionnaire survey of companies operating in a total of 17 regions of Russia during the fourth quarter of 2015, we empirically examined whether regional heterogeneity exists between eastern and western regions with respect to corporate governance systems. To answer this question, using the findings and empirical evidence of previous studies as the reference standard, we investigated whether the stylized facts about the corporate governance system in Russian industrial firms and listed companies are applicable to firms in a wide range of industrial sectors and to identify whether there are significant differences between companies in the east and those in the west from this point of view.

The results of regression analyses reported in Section 4 demonstrate that the regional heterogeneity in corporate governance systems identified by our survey results is largely due to differences between the eastern and western regions in terms of ownership structure and other firm-level attributes. This finding is clearly reflected in the fact that the EAST variable was estimated to be insignificant, while a series of control variables showed significant estimates in many regression models.

It is extremely noteworthy, however, that in models that employed the probability of establishing a statutory company organ and the probability of executing an external audit as dependent variables, the $E A S T$ variable was repeatedly estimated to be significant with a negative sign. These empirical results demonstrate not only that eastern companies are more reluctant than their western counterparts to introduce a governance system to monitor and supervise management, but also that this trend could not simply be explained by differences in firm-level attributes, indicating the presence of pronounced regional heterogeneity between the eastern and western regions of Russia.

14 Although a detailed interpretation of estimates for control variables is omitted due to space limitations, all variables with a statistically significant coefficient are in agreement with the empirical results presented in Iwasaki (2008, 2014a, 2014b). We also note that variables such as total sales, respondents' subjective evaluation of their companies' current financial health, and capital investment performance in the past five years were also estimated; however, all of these variables were found to be insignificant. 
We conjecture that the reasons behind the presence of regional heterogeneity could include the immaturity of civil society; a lack of understanding about the importance of corporate governance on the part of local governments, investors, and other stakeholders; the backwardness of the corporate service industry; and a lack of human resources in the eastern region as compared to the west. Further investigation of the causes of this phenomenon and the implementation of appropriate political measures will contribute to improving not only the management systems in the eastern companies but also the quality of the regional economies.

The policy implications of the present study do not stop there. The most important finding of the ERINA Enterprise Survey is that the various problems surrounding the Russian corporate governance system identified by previous studies by observing industrial firms and listed companies are, in fact, common and chronic issues that affect all Russian business sectors. It is highly likely that the corporate governance syndrome in Russia, which is characterized by the choice of closed corporate forms by the overwhelming majority of Russian companies, the polarization trend in boards of directors and audit committees in terms of independence from management, the reluctance to employ independent directors or expert auditors, and the strong preference for local auditors and indigenous audit firms as external auditors, is a deep-rooted structural issue that is far more serious than we had expected. To facilitate the fundamental resolution of this challenging issue, the federal government must work in close collaboration with local authorities and industries to pursue corporate governance reform more boldly than ever before.

\section{References}

Ankudinov, Andrei B. and Oleg Lebedev (2016) Dividend Payouts and Company Ownership Structure amid the Global Financial Crisis: Evidence from Russia, Post-Communist Economies, Vol. 28, No. 3, pp. 384-404.

Arai, Hirofumi and Ichiro Iwasaki (2016) Market Quality in the Russian Far East from the Viewpoint of Company Management: Preliminary Report on Microeconomic Comparative Analysis with European Regions, ERINA Discussion Paper No. 1602e, Niigata: Economic Research Institute for Northeast Asia (also available as RRC Working Paper No. 62, Kunitachi: Russian Research Center, Institute of Economic Research of Hitotsubashi University).

Bevan, Alan A., Saul Estrin, Boris Kuznetsov, Mark E. Schaffer, Manuela Angelucci, Julian Fennema and Giovanni Mangiarotti (2001) The Determinants of Privatized Enterprise Performance in Russia, Working Paper No. 452, Ann Arbor: William Davidson Institute, University of Michigan Business School.

Blasi, Joseph and Andrei Shleifer (1996) Corporate Governance in Russia: An Initial Look, In: Frydman, Roman, Cheryl W. Gray and Andrzej Rapaczynski, eds., Corporate Governance in Central Europe and Russia Volume 2: Insiders and the State, Budapest: Central European University Press, pp. 78-108. 
Dolgopyatova, Tatiana G. and Ichiro Iwasaki (2006) Exploring Russian Corporations: Interim Report on the Japan-Russia Joint Research Project on Corporate Governance and Integration Processes in the Russian Economy, Discussion Paper No. B35, Kunitachi: Institute of Economic Research of Hitotsubashi University.

Dolgopyatova, Tatiana G., Ichiro Iwasaki and Andrei A. Yakovlev, eds. (2009) Organization and Development of Russian Business: A Firm-Level Analysis, Basingstoke: Palgrave Macmillan.

Filatotchev, Igor, Mike Wright, Trevor Buck and Natalya Dyomina (1999a) Exporting and Restructuring in Privatized Firms from Russia, Ukraine and Belarus, The World Economy, Vol. 22, No. 7, pp. 1013-1037.

Filatotchev, Igor, Mike Wright, Trevor Buck and Vladimir Zhukov (1999b) Corporate Entrepreneurs and Privatized Firms in Russia, Ukraine, and Belarus, Journal of Business Venturing, Vol. 14, No. 5/6, pp. 475-492.

Greene, William H. (2017) Econometric Analysis, Eighth Edition, Boston and Tokyo: Prentice Hall.

Hermalin, Benjamin E. and Michael S. Weisbach (1998) Endogenously Chosen Board of Directors and Their Monitoring of the CEO, American Economic Review, Vol. 88, No. 1, pp. 96-118.

Iwasaki, Ichiro (2007a) Corporate Law and Governance Mechanism in Russia, In: Dallago, Bruno, and Ichiro Iwasaki, eds., Corporate Restructuring and Governance in Transition Economies, Palgrave Macmillan, Basingstoke, pp. 213-249.

Iwasaki, Ichiro (2007b) Enterprise Reform and Corporate Governance in Russia: A Quantitative Survey, Journal of Economic Surveys, Vol. 21, No. 5, pp. 849-902.

Iwasaki, Ichiro (2008) The Determinants of Board Composition in a Transforming Economy: Evidence from Russia, Journal of Corporate Finance, Vol. 14, No. 5, pp. 532-549.

Iwasaki, Ichiro (2013) Firm-Level Determinants of Board System Choice: Evidence from Russia, Comparative Economic Studies, Vol. 55, No. 4, pp. 636-671.

Iwasaki, Ichiro (2014a) Corporate Form, Institutional Complementarity, and Organizational Behavior: Open versus Closed Joint-stock Companies in Russia, In: Boubaker, Sabri, and Duc Khuong Nuyen, eds., Corporate Governance in Emerging Markets: Theories, Practices and Cases, Berlin: Springer Verlag, pp. 157-195.

Iwasaki, Ichiro (2014b) What Determines Audit Independence and Expertise in Russia? Firm-level Evidence, Corporate Ownership and Control, Vol. 11, No. 2, pp. 81-107.

Iwasaki, Ichiro (2016) The Evolution of Corporate Governance in the Global Financial Crisis: The Case of Russian Industrial Firms, Journal of Governance and Regulation, Vol. 5, No. 4, pp. 1639.

Judge, William, Irina Naoumova and Nadejda Koutzevol (2003) Corporate Governance and Firm Performance in Russia: An Empirical Study, Journal of World Business, Vol. 38, No. 4, pp. 385396.

Liljeblom, Eva and Benjamin Maury (2016) Shareholder Protection, Ownership, and Dividends: Russian Evidence, Emerging Markets Finance and Trade, Vol. 52, No. 10, pp. 2414-2433.

Moser, Nat (2016) Ownership and Enterprise Performance in the Russian Oil Industry, 1992-2012, Post-Communist Economies, Vol. 28, No. 1, pp. 72-86.

Muravyev, Alexander (2017) Boards of Directors in Russian Publicly Traded Companies in 19982014: Structure, Dynamics and Performance Effects, Economic Systems, Vol. 41, No. 1, pp. 5-25. 
Muravyev, Alexander, Irina Berezinets and Yulia Ilina (2014) The Structure of Corporate Boards and Private Benefits of Control: Evidence from the Russian Stock Exchange, International Review of Financial Analysis, Vol. 34, pp. 247-261.

Oda, Hiroshi (2007) Russian Commercial Law, Third Edition, Leiden and Boston: Martinus Nijhoff Publishers.

Peng, Mike W., Trevor Buck and Igor Filatotchev (2003) Do Outside Directors and New Managers Help Improve Firm Performance? An Exploratory Study in Russian Privatization, Journal of World Business, Vol. 38, No. 4, pp. 348-360.

Puffer, Sheila M. and Daniel J. McCarthy (2011) Two Decades of Russian Business and Management Research: An Institutional Theory Perspective, Academy of Management Perspectives, Vol. 25, No. 2, pp. 21-36.

ROSSTAT (Федеральная Служба Государственной Статистики) (2016) Социальноэкономическое положение России: Январь 2016 года, Москва: Федеральная Служба Государственной Статистики.

World Bank (2008) Doing Business 2008, Fifth Edition, Washington D.C.: World Bank.

World Bank (2017) Doing Business 2017: Equal Opportunity for All, Fourteenth Edition, Washington D. C.: World Bank.

Wright, Mike, Trevor Buck and Igor Filatotchev (1998) Bank and Investment Fund Monitoring of Privatized Firms in Russia, Economics of Transition, Vol. 6, No. 2, pp. 361-387. 
Table 1. Breakdown of profit organizations in the Russian Federation by legal form of incorporation (January 2016)

\begin{tabular}{lrr}
\hline \hline & $\begin{array}{c}\text { Number of } \\
\text { companies } \\
\text { (in thousands) }\end{array}$ & $\begin{array}{c}\text { Share } \\
(\%)\end{array}$ \\
\hline All profit organizations & 4,237 & 100.0 \\
Business partnerships and companies & 4,159 & 98.2 \\
Joint-stock companies & 129 & 3.0 \\
Limited liability companies & 4,030 & 95.1 \\
Unitary enterprises & 21 & 0.5 \\
Other & 57 & 1.3 \\
\hline
\end{tabular}

Source: ROSSTAT (2016, p. 132) 
Table 2. Statutory company organs within a limited liability company and a joint-stock company in Russia

\begin{tabular}{|c|c|c|c|c|}
\hline & \multicolumn{2}{|c|}{ Limited liability company } & \multicolumn{2}{|c|}{ Joint-stock company } \\
\hline & Organ name & $\begin{array}{l}\text { Obligation of } \\
\text { establishment }\end{array}$ & Organ name & $\begin{array}{l}\text { Obligation of } \\
\text { establishment }\end{array}$ \\
\hline Supreme decision-making body & $\begin{array}{c}\text { General meeting of } \\
\text { members }\end{array}$ & Yes & $\begin{array}{l}\text { General meeting of } \\
\text { shareholders }\end{array}$ & Yes \\
\hline \multirow[b]{2}{*}{ Executive body } & Single executive body & Yes & Single executive body & Yes \\
\hline & $\begin{array}{c}\text { Collective executive } \\
\text { board }\end{array}$ & No & $\begin{array}{c}\text { Collective executive } \\
\text { board }\end{array}$ & No \\
\hline Management oversight body & $\begin{array}{l}\text { Board of directors } \\
\text { (Supervisory board) }\end{array}$ & No & $\begin{array}{l}\text { Board of directors } \\
\text { (Supervisory board) }\end{array}$ & Yes $^{a}$ \\
\hline Financial oversight body & $\begin{array}{l}\text { Audit committee } \\
\text { (Auditor) }\end{array}$ & Yes $^{\mathrm{b}}$ & $\begin{array}{l}\text { Audit committee } \\
\text { (Auditor) }\end{array}$ & Yes \\
\hline
\end{tabular}

\section{Notes:}

${ }^{a}$ Mandatory if there are more than 50 shareholders in the company

${ }^{\mathrm{b}}$ Mandatory if there are more than 15 members in the company

Source: Federal Law of Joint-stock Companies and Federal Law of Limited Liability Companies that are effective as of November 1, 2017 
Table 3. Survey results regarding legal forms of incorporation

\begin{tabular}{|c|c|c|c|c|c|c|}
\hline & \multicolumn{2}{|c|}{ All surveyed firms } & \multicolumn{2}{|c|}{ Eastern region } & \multicolumn{2}{|c|}{ Western region } \\
\hline & $\begin{array}{c}\text { Number of } \\
\text { firms }\end{array}$ & $\begin{array}{c}\text { Share } \\
(\%) \\
\end{array}$ & $\begin{array}{c}\text { Number of } \\
\text { firms }\end{array}$ & $\begin{array}{c}\text { Share } \\
(\%) \\
\end{array}$ & $\begin{array}{c}\text { Number of } \\
\text { firms }\end{array}$ & $\begin{array}{c}\text { Share } \\
(\%) \\
\end{array}$ \\
\hline Public (open) joint-stock companies & 116 & 15.6 & 63 & 17.6 & 53 & 13.8 \\
\hline Private (closed) joint-stock companies & 76 & 10.2 & 26 & 7.3 & 50 & 13.0 \\
\hline Limited liability companies & 550 & 74.1 & 269 & 75.1 & 281 & 73.2 \\
\hline Total & 742 & 100.0 & 358 & 100.0 & 384 & 100.0 \\
\hline
\end{tabular}


Table 4. Survey results regarding the establishment, membership size, and composition of the board of directors

(a) Establishment of the board of directors

\begin{tabular}{|c|c|c|c|c|c|c|}
\hline & \multicolumn{2}{|c|}{ All surveyed firms } & \multicolumn{2}{|c|}{ Eastern region $^{\mathrm{a}}$} & \multicolumn{2}{|c|}{ Western region } \\
\hline & $\begin{array}{c}\text { Number of } \\
\text { firms }\end{array}$ & $\begin{array}{c}\text { Share } \\
(\%)\end{array}$ & $\begin{array}{c}\text { Number of } \\
\text { firms }\end{array}$ & $\begin{array}{c}\text { Share } \\
(\%)\end{array}$ & $\begin{array}{c}\text { Number of } \\
\text { firms }\end{array}$ & $\begin{array}{c}\text { Share } \\
(\%)\end{array}$ \\
\hline Firms that establish a board of directors & 212 & 28.6 & 90 & 25.1 & 122 & 31.8 \\
\hline Firms that do not establish a board of directors & 530 & 71.4 & 268 & 74.9 & 262 & 68.2 \\
\hline Total & 742 & 100.0 & 358 & 100.0 & 384 & 100.0 \\
\hline
\end{tabular}

(b) Membership size of the board of directors ${ }^{\text {b }}$

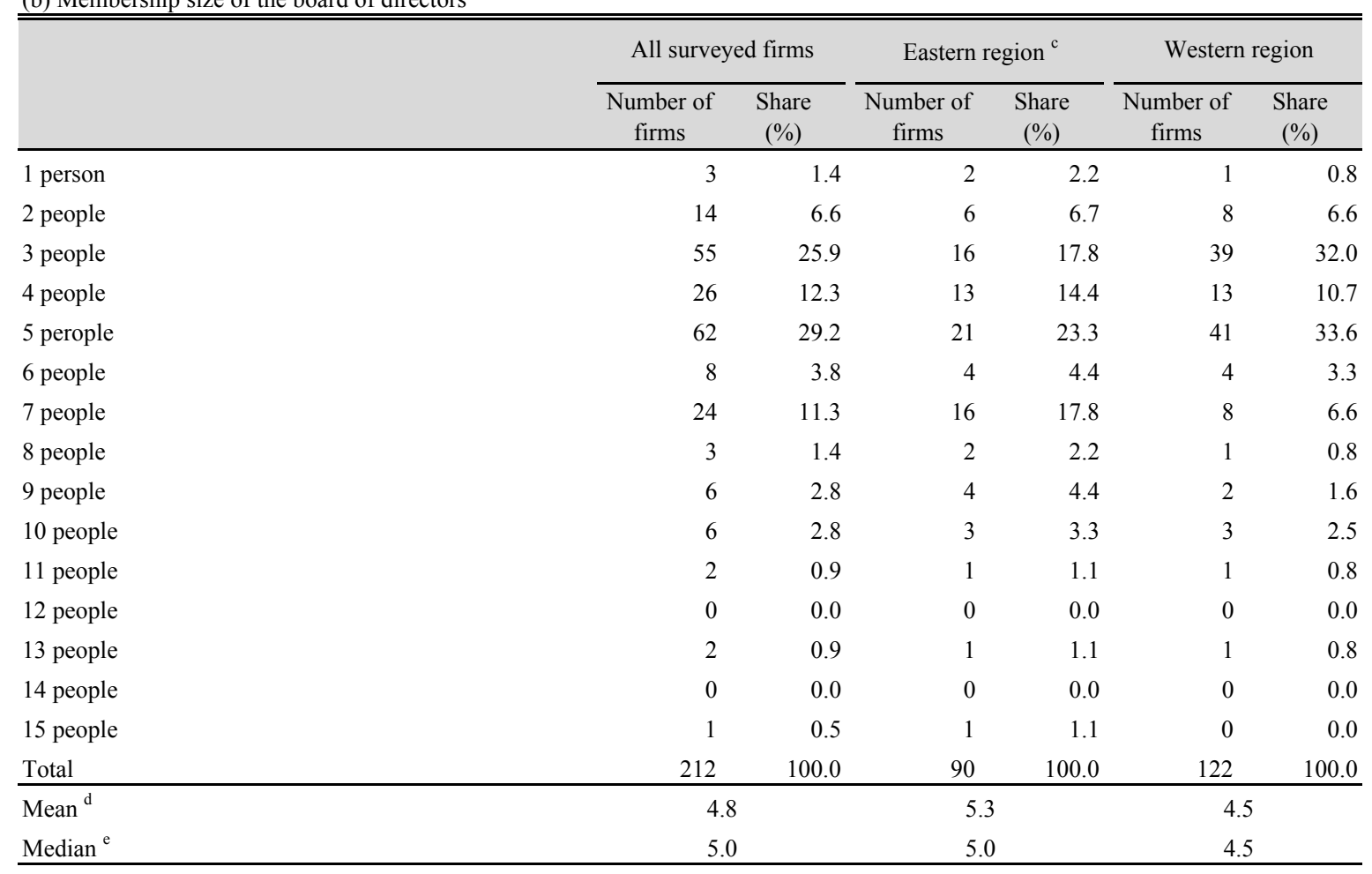

(c) Composition of board directors ${ }^{\mathrm{b}}$

\begin{tabular}{|c|c|c|c|c|c|c|}
\hline & \multicolumn{2}{|c|}{ All surveyed firms } & \multicolumn{2}{|c|}{ Eastern region ${ }^{\mathrm{f}, \mathrm{g}}$} & \multicolumn{2}{|c|}{ Western region } \\
\hline & $\begin{array}{c}\text { Number of } \\
\text { people }\end{array}$ & $\begin{array}{l}\text { Share } \\
(\%)\end{array}$ & $\begin{array}{c}\text { Number of } \\
\text { people }\end{array}$ & $\begin{array}{l}\text { Share } \\
(\%)\end{array}$ & $\begin{array}{c}\text { Number of } \\
\text { people }\end{array}$ & $\begin{array}{l}\text { Share } \\
(\%)\end{array}$ \\
\hline Inside directors & 564 & 54.9 & 218 & 45.8 & 346 & 62.8 \\
\hline Management representatives & 511 & 49.8 & 210 & 44.1 & 301 & 54.6 \\
\hline Representatives of employees and labor unions & 53 & 5.2 & 8 & 1.7 & 45 & 8.2 \\
\hline Outside directors & 463 & 45.1 & 258 & 54.2 & 205 & 37.2 \\
\hline Representatives of federal government agencies & 8 & 0.8 & 4 & 0.8 & 4 & 0.7 \\
\hline Representatives of local governments & 41 & 4.0 & 18 & 3.8 & 23 & 4.2 \\
\hline Representatives of non-employee private shareholders & 270 & 26.3 & 142 & 29.8 & 128 & 23.2 \\
\hline Independent directors & 87 & 8.5 & 37 & 7.8 & 50 & 9.1 \\
\hline Other outside members & 57 & 5.6 & 57 & 12.0 & 0 & 0.0 \\
\hline Total & 1027 & 100.0 & 476 & 100.0 & 551 & 100.0 \\
\hline \multicolumn{7}{|c|}{ Notes: } \\
\hline \multicolumn{7}{|c|}{${ }^{\mathrm{a}}$ Test of proportions of firms that establish a board of directors with the western regions: $z=-1.9980, p=0.0457$} \\
\hline \multicolumn{7}{|c|}{${ }^{\mathrm{b}}$ Survey results limited to companies having a board of directors } \\
\hline \multicolumn{7}{|c|}{${ }^{\mathrm{c}}$ Test of equality with the western region: $\mathrm{Chi} 2=15.7409, p=0.2033$, Cramer $V=0.2805$} \\
\hline \multicolumn{7}{|c|}{ Test of means between the eastern and western regions: $t=2.4734, p=0.0142$} \\
\hline \multicolumn{7}{|c|}{${ }^{\mathrm{e}}$ Wilcoxon (Mann-Whitney) rank sum test between the western and eastern regions: $z=2.332, p=0.0197$} \\
\hline \multicolumn{7}{|c|}{${ }^{\mathrm{f}}$ Test of proportions of inside directors with the western region: $z=5.4590, p=0.0000$} \\
\hline \multicolumn{7}{|c|}{${ }^{\mathrm{g}}$ Test of equality with the western region using seven subcategories of board directors: Chi2 $=97.3559, p=0.0000$, Cramer $V=0.3078$} \\
\hline Source : ERINA Enterprise Survey & & & & & & \\
\hline
\end{tabular}




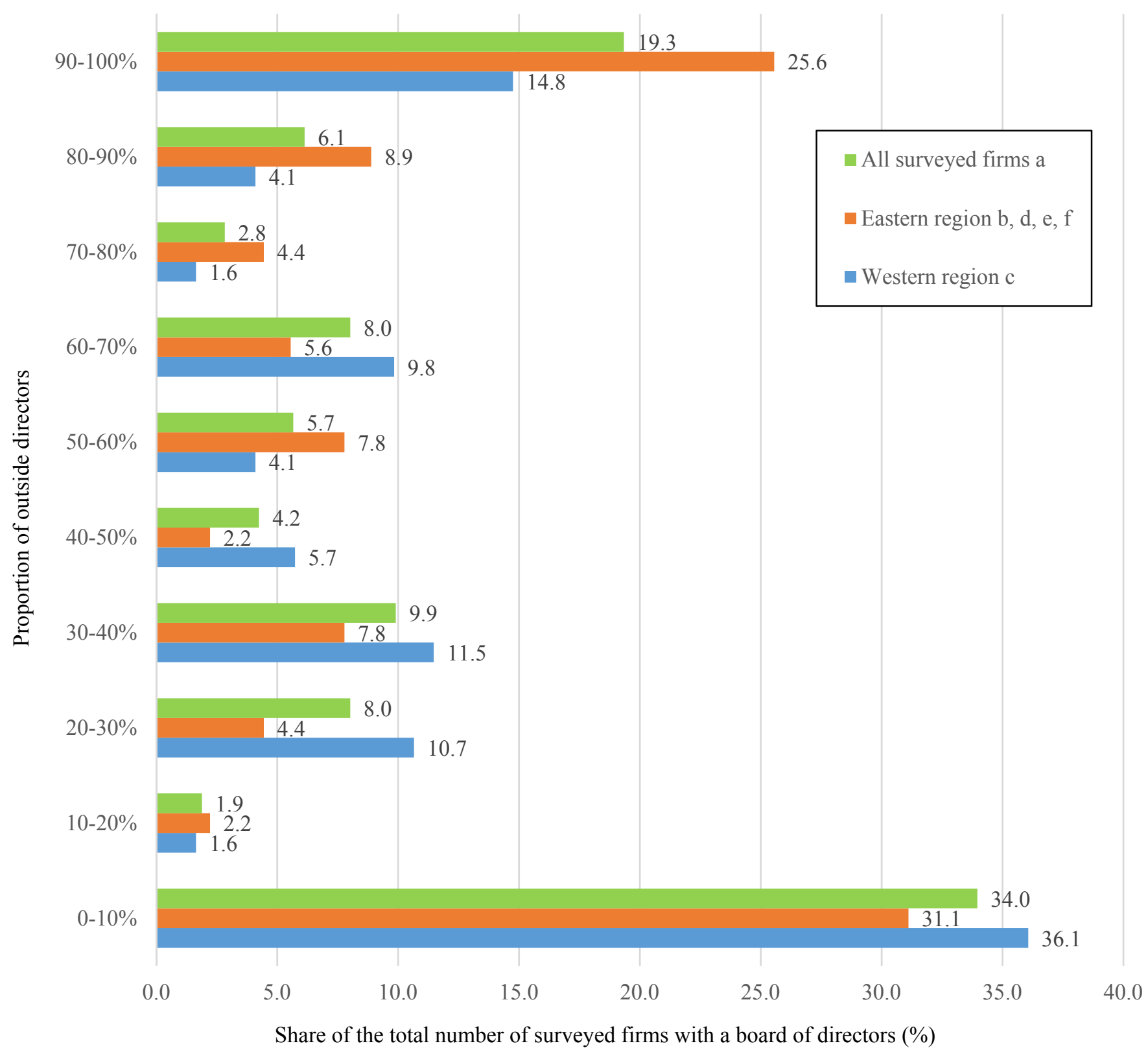

Figure 1. Distribution of the proportion of outside directors

Notes:

${ }^{\text {a }}$ Limited to 212 companies having a board of directors; Mean: $41.7 \%$, median: $33.3 \%$

${ }^{\mathrm{b}}$ Mean: $48.6 \%$, median: $50.0 \%$

${ }^{\mathrm{c}}$ Mean: $36.5 \%$, median: $33.3 \%$

${ }^{\mathrm{d}}$ Test of equality with the western region: $\mathrm{Chi} 2=13.5562, p=0.1390$, Cramer $V=0.2603$

${ }^{\mathrm{e}}$ Test of means with the western region: $t=2.2782, p=0.0237$

${ }^{\mathrm{f}}$ Wilcoxon (Mann-Whitney) rank sum test with the western region: $z=2.029, p=0.0424$

Source : ERINA Enterprise Survey 


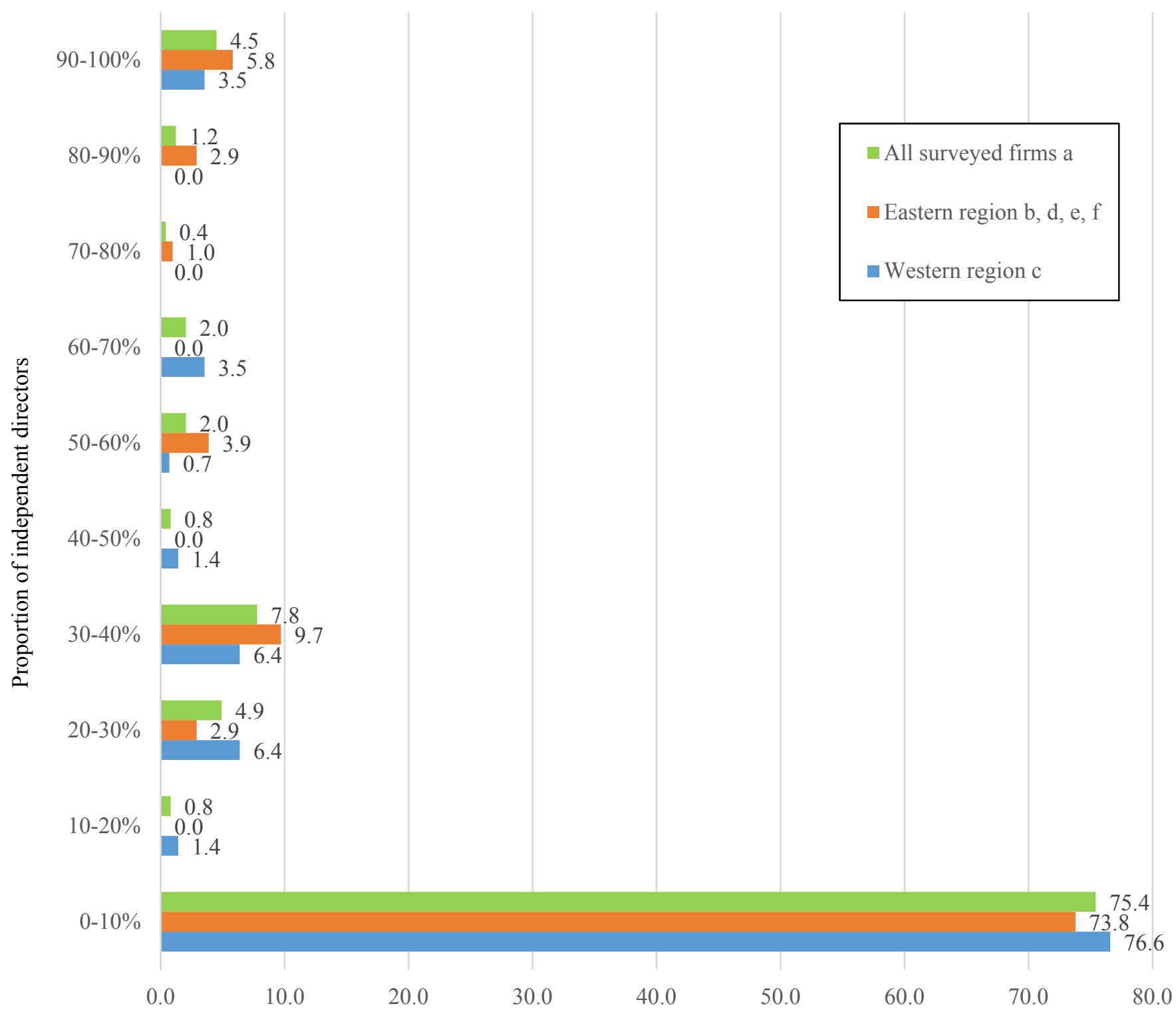

Share of the total number of surveyed firms with a board of directors (\%)

Figure 2. Distribution of the proportion of independent directors

Notes :

${ }^{\text {a }}$ Limited to 212 companies having a board of directors; Mean: $8.3 \%$, median: $0.0 \%$

${ }^{\mathrm{b}}$ Mean: $6.7 \%$, median: $0.0 \%$

${ }^{\mathrm{c}}$ Mean: $9.5 \%$, median: $0.0 \%$

${ }^{\mathrm{d}}$ Test of equality with the western region: Chi2 $=13.9475, p=0.1242$, Cramer $V=0.2640$

${ }^{\mathrm{e}}$ Test of means with the western region: $t=0.8556, p=0.3932$

${ }^{\mathrm{f}}$ Wilcoxon (Mann-Whitney) rank sum test with the western region: $z=-1.133, p=0.2573$

Source : ERINA Enterprise Survey 
Table 5. Survey results regarding the appointment route of chairmen of the board ${ }^{\text {a }}$

\begin{tabular}{|c|c|c|c|c|c|c|}
\hline & \multicolumn{2}{|c|}{ All surveyed firms } & \multicolumn{2}{|c|}{ Eastern region ${ }^{b, c}$} & \multicolumn{2}{|c|}{ Western region } \\
\hline & $\begin{array}{c}\text { Number of } \\
\text { people }\end{array}$ & $\begin{array}{c}\text { Share } \\
(\%)\end{array}$ & $\begin{array}{c}\text { Number of } \\
\text { people }\end{array}$ & $\begin{array}{c}\text { Share } \\
(\%)\end{array}$ & $\begin{array}{c}\text { Number of } \\
\text { people }\end{array}$ & $\begin{array}{c}\text { Share } \\
(\%)\end{array}$ \\
\hline Inside and quasi-inside board chairmen & 140 & 72.2 & 57 & 73.1 & 83 & 71.6 \\
\hline Promoted from inside the company & 122 & 62.9 & 45 & 57.7 & 77 & 66.4 \\
\hline Elected from an affiliated business group or a business partner & 18 & 9.3 & 12 & 15.4 & 6 & 5.2 \\
\hline Outside board chairmen & 54 & 27.8 & 21 & 26.9 & 33 & 28.4 \\
\hline Elected from a federal government agency or parliament & 4 & 2.1 & 2 & 2.6 & 2 & 1.7 \\
\hline Elected from a regional or local government or parliament & 8 & 4.1 & 0 & 0.0 & 8 & 6.9 \\
\hline Elected from another company operating in the same industry & 30 & 15.5 & 14 & 17.9 & 16 & 13.8 \\
\hline Elected from another company operating in a different industry & 12 & 6.2 & 5 & 6.4 & 7 & 6.0 \\
\hline Total & 194 & 100.0 & 78 & 100.0 & 116 & 100.0 \\
\hline
\end{tabular}

Notes:

${ }^{\text {a }}$ Survey results limited to companies having a board of directors

${ }^{\mathrm{b}}$ Test of proportions of inside and quasi-inside board chairmen with the western region: $z=0232, p=0.8162$

${ }^{\mathrm{c}}$ Test of equality with the western region using six subcategories of board chairman: Chi2 $=11.8723, p=0.0365$, Cramer $V=0.2473$

Source : ERINA Enterprise Survey 
Table 6. Survey results regarding the establishment, membership size, and composition of an audit committee ${ }^{\mathrm{a}}$

(a) Establishment of an audit committee

\begin{tabular}{|c|c|c|c|c|c|c|}
\hline & \multicolumn{2}{|c|}{ All surveyed firms } & \multicolumn{2}{|c|}{ Eastern region ${ }^{\mathrm{b}}$} & \multicolumn{2}{|c|}{ Western region } \\
\hline & $\begin{array}{c}\text { Number of } \\
\text { firms }\end{array}$ & $\begin{array}{c}\text { Share } \\
(\%)\end{array}$ & $\begin{array}{c}\text { Number of } \\
\text { firms }\end{array}$ & $\begin{array}{c}\text { Share } \\
(\%)\end{array}$ & $\begin{array}{c}\text { Number of } \\
\text { firms }\end{array}$ & $\begin{array}{c}\text { Share } \\
(\%)\end{array}$ \\
\hline Firms that establish an audit committee & 244 & 34.1 & 103 & 30.5 & 141 & 37.4 \\
\hline Firms that do not establish an audit committee & 471 & 65.9 & 235 & 69.5 & 236 & 62.6 \\
\hline Total & 715 & 100.0 & 338 & 100.0 & 377 & 100.0 \\
\hline
\end{tabular}

(b) Membership size of the audit committee ${ }^{\mathrm{c}}$

\begin{tabular}{|c|c|c|c|c|c|c|}
\hline & \multicolumn{2}{|c|}{ All surveyed firms } & \multicolumn{2}{|c|}{ Eastern region ${ }^{\mathrm{d}}$} & \multicolumn{2}{|c|}{ Western region } \\
\hline & $\begin{array}{c}\text { Number of } \\
\text { firms }\end{array}$ & $\begin{array}{c}\text { Share } \\
(\%)\end{array}$ & $\begin{array}{c}\text { Number of } \\
\text { firms }\end{array}$ & $\begin{array}{c}\text { Share } \\
(\%)\end{array}$ & $\begin{array}{c}\text { Number of } \\
\text { firms }\end{array}$ & $\begin{array}{c}\text { Share } \\
(\%)\end{array}$ \\
\hline 1 person & 9 & 3.7 & 8 & 7.8 & 1 & 0.7 \\
\hline 2 people & 36 & 14.8 & 13 & 12.6 & 23 & 16.3 \\
\hline 3 people & 115 & 47.1 & 51 & 49.5 & 64 & 45.4 \\
\hline 4 people & 21 & 8.6 & 9 & 8.7 & 12 & 8.5 \\
\hline 5 people & 37 & 15.2 & 13 & 12.6 & 24 & 17.0 \\
\hline 6 people & 10 & 4.1 & 4 & 3.9 & 6 & 4.3 \\
\hline 7 people & 6 & 2.5 & 0 & 0.0 & 6 & 4.3 \\
\hline 8 people & 3 & 1.2 & 1 & 1.0 & 2 & 1.4 \\
\hline 9 people & 1 & 0.4 & 1 & 1.0 & 0 & 0.0 \\
\hline 10 people & 0 & 0.0 & 0 & 0.0 & 0 & 0.0 \\
\hline 11 people & 0 & 0.0 & 0 & 0.0 & 0 & 0.0 \\
\hline 12 people & 4 & 1.6 & 2 & 1.9 & 2 & 1.4 \\
\hline 13 people & 1 & 0.4 & 1 & 1.0 & 0 & 0.0 \\
\hline 14 people & 0 & 0.0 & 0 & 0.0 & 0 & 0.0 \\
\hline 15 people & 1 & 0.4 & 0 & 0.0 & 1 & 0.7 \\
\hline Total & 244 & 100.0 & 103 & 100.0 & 141 & 100.0 \\
\hline Mean $^{\mathrm{e}}$ & 3.7 & & 3. & & 3.8 & \\
\hline Median $^{\mathrm{f}}$ & 3.0 & & 3. & & 3.0 & \\
\hline
\end{tabular}

(c) Composition of the audit committee ${ }^{\mathrm{c}}$

\begin{tabular}{|c|c|c|c|c|c|c|}
\hline & \multicolumn{2}{|c|}{ All surveyed firms } & \multicolumn{2}{|c|}{ Eastern region ${ }^{\mathrm{g}, \mathrm{h}}$} & \multicolumn{2}{|c|}{ Western region } \\
\hline & $\begin{array}{c}\text { Number of } \\
\text { people }\end{array}$ & $\begin{array}{c}\text { Share } \\
(\%)\end{array}$ & $\begin{array}{c}\text { Number of } \\
\text { people }\end{array}$ & $\begin{array}{c}\text { Share } \\
(\%)\end{array}$ & $\begin{array}{c}\text { Number of } \\
\text { people }\end{array}$ & $\begin{array}{c}\text { Share } \\
(\%)\end{array}$ \\
\hline Inside auditors & 601 & 66.5 & 203 & 55.5 & 398 & 74.0 \\
\hline Management representatives & 426 & 47.1 & 155 & 42.3 & 271 & 50.4 \\
\hline Representatives of employees and labor unions & 175 & 19.4 & 48 & 13.1 & 127 & 23.6 \\
\hline Outside auditors & 303 & 33.5 & 163 & 44.5 & 140 & 26.0 \\
\hline Representatives of government agencies & 47 & 5.2 & 16 & 4.4 & 31 & 5.8 \\
\hline Representatives of non-employee private shareholders & 72 & 8.0 & 23 & 6.3 & 49 & 9.1 \\
\hline Expert auditors & 120 & 13.3 & 60 & 16.4 & 60 & 11.2 \\
\hline Other outside members & 64 & 7.1 & 64 & 17.5 & 0 & 0.0 \\
\hline Total & 904 & 100.0 & 366 & 100.0 & 538 & 100.0 \\
\hline \multicolumn{7}{|l|}{ Notes: } \\
\hline \multicolumn{7}{|l|}{ a Except 27 firms that provided invalid responses } \\
\hline \multicolumn{7}{|c|}{${ }^{b}$ Test of proportions of firms that establish an audit committee with the western region: $z=-1.9504, p=0.0511$} \\
\hline \multicolumn{7}{|c|}{ ' Survey results limited to companies having an audit committee } \\
\hline \multicolumn{7}{|c|}{${ }^{\mathrm{d}}$ Test of equality with the western region: $\mathrm{Chi} 2=14.2714, p=0.2183$, Cramer $V=0.2671$} \\
\hline \multicolumn{7}{|c|}{${ }^{\mathrm{e}}$ Test of means between the eastern and western regions: $t=-1.0610, p=0.2897$} \\
\hline \multicolumn{7}{|c|}{${ }^{\mathrm{f}}$ Wilcoxon (Mann-Whitney) rank sum test between the western and eastern regions: $z=-1.434, p=0.1514$} \\
\hline \multicolumn{7}{|c|}{${ }^{\mathrm{g}}$ Test of proportions of inside directors with the western region: $z=-5.7881, p=0.0000$} \\
\hline${ }^{\mathrm{h}}$ Test of equality with the western region using seven subcatege & ies of corporat & uditor: $\mathrm{Chi} 2$ & $=116.9332, p$ & 000, Cran & $V=0.3596$ & \\
\hline
\end{tabular}




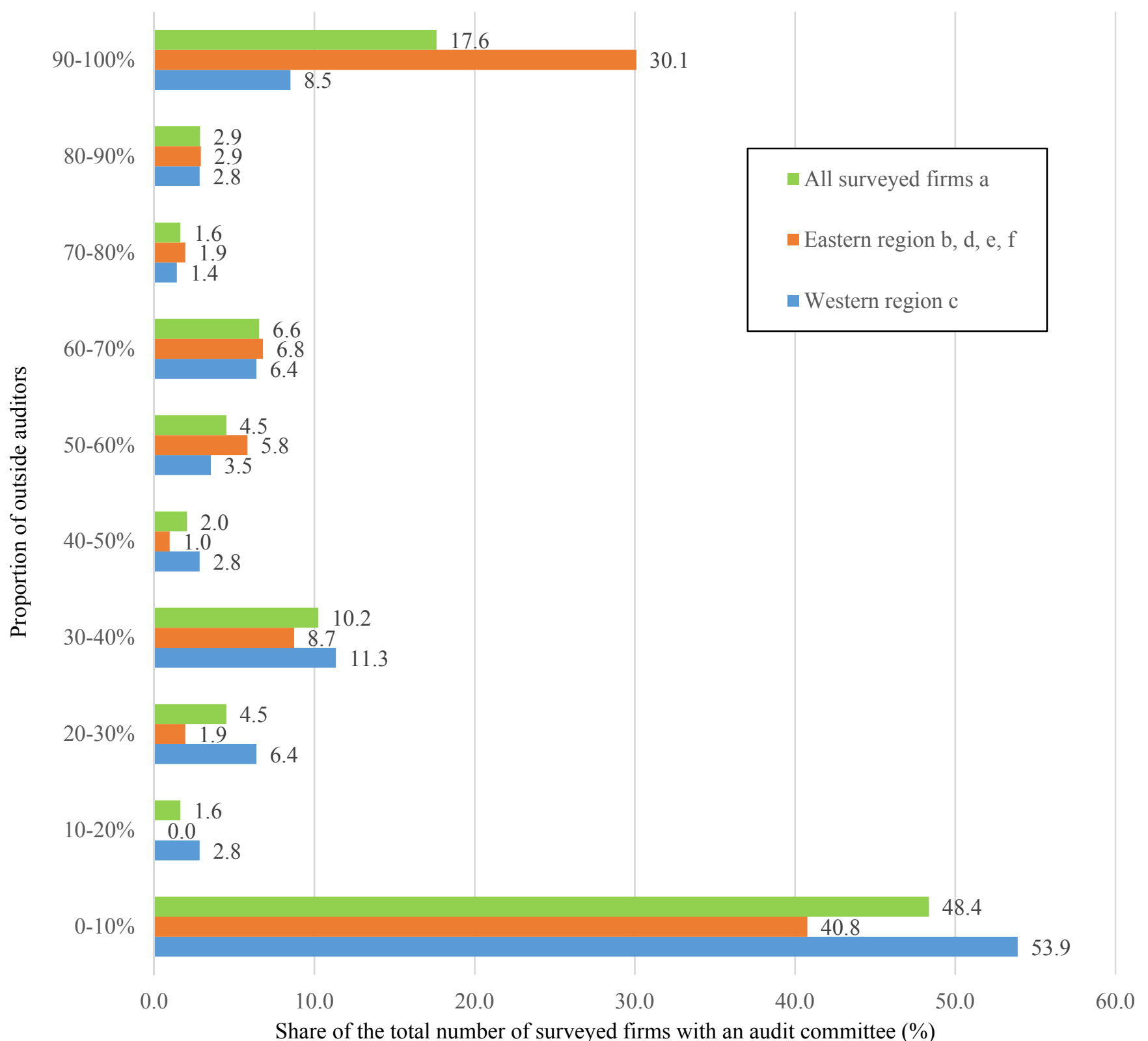

Figure 3. Distribution of the proportion of outside auditors

Notes :

${ }^{\text {a }}$ Limited to 244 companies having an audit committee; Mean: $33.2 \%$, median: $18.4 \%$

${ }^{\mathrm{b}}$ Mean: $45.1 \%$, median: $33.3 \%$

${ }^{\mathrm{c}}$ Mean: $24.5 \%$, median: $0.0 \%$

${ }^{\mathrm{d}}$ Test of equality with the western region: Chi2 $=20.9982, p=0.0126$, Cramer $V=0.3240$

${ }^{\mathrm{e}}$ Test of means with the western region: $t=4.2160, p=0.0000$

${ }^{\mathrm{f}}$ Wilcoxon (Mann-Whitney) rank sum test with the western region: $z=3.543, p=0.0004$

Source: ERINA Enterprise Survey 


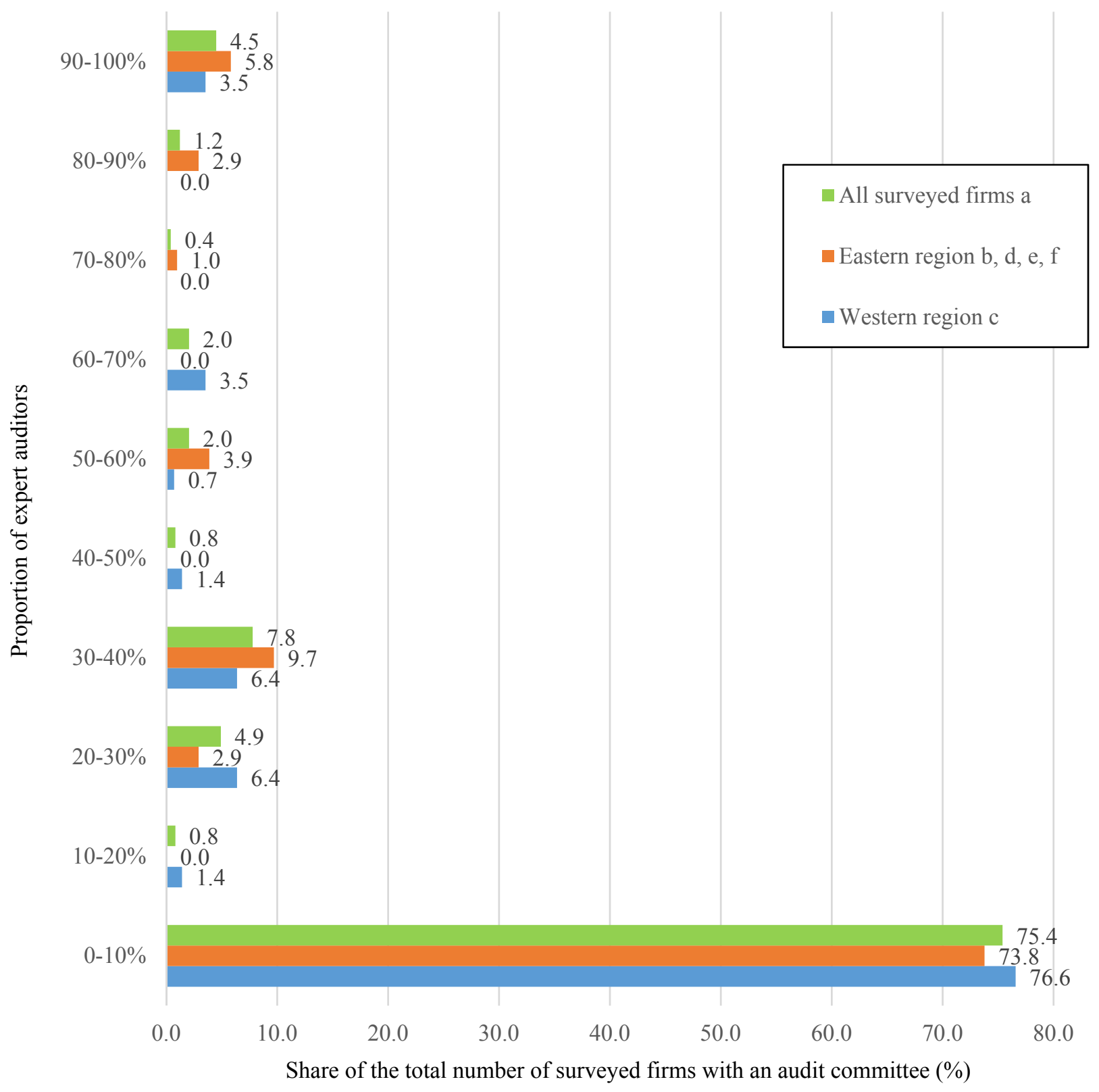

Figure 4. Distribution of the proportion of expert auditors

Notes:

${ }^{\text {a }}$ Limited to 244 companies having an audit committee; Mean: $12.4 \%$, median: $0.0 \%$

${ }^{\mathrm{b}}$ Mean: $14.8 \%$, median: $0.0 \%$

${ }^{\mathrm{c}}$ Mean: $10.6 \%$, median: $0.0 \%$

${ }^{\mathrm{d}}$ Test of equality with the western region: Chi2 $=15.0501, p=0.0895$, Cramer $V=0.2743$

${ }^{\mathrm{e}}$ Test of means with the western region: $t=-1.2544, p=0.2109$

${ }^{\mathrm{f}}$ Wilcoxon (Mann-Whitney) rank sum test with the western region: $z=0.696, p=0.4865$

Source : ERINA Enterprise Survey 
Table 8. Definition and descriptive statistics of the variables used in regression analysi

\begin{tabular}{|c|c|c|c|c|c|c|}
\hline \multirow{2}{*}{ Variable name } & \multirow{2}{*}{ Definition } & \multicolumn{5}{|c|}{ Descriptive statistics } \\
\hline & & $\begin{array}{c}\text { Mean/ } \\
\text { proportion }\end{array}$ & S.D. & Median & Min. & Max. \\
\hline$A U D C O M$ & Proportion of outside auditors ${ }^{\mathrm{a}}$ & 0.332 & 0.389 & 0.184 & 0.000 & 1.000 \\
\hline$A U D E X P$ & Proportion of expert auditors ${ }^{a}$ & 0.124 & 0.259 & 0.000 & 0.000 & 1.000 \\
\hline$A U D F I R$ & Dummy for firms having an audit committee & 0.341 & 0.474 & 0 & 0 & 1 \\
\hline$B A N C R E$ & The use of bank credits and their average lending period ${ }^{b}$ & 2.430 & 2.227 & 3 & 0 & 6 \\
\hline BOACOM & Proportion of outside directors ${ }^{\mathrm{a}}$ & 0.417 & 0.386 & 0.333 & 0.000 & 1.000 \\
\hline$B O A L E A$ & Outsideness of board chairman ${ }^{c}$ & 0.649 & 0.888 & 0 & 0 & 2 \\
\hline BODFIR & Dummy for firms having a board of directors & 0.286 & 0.452 & 0 & 0 & 1 \\
\hline COMSIZ & Average annual number of employees ${ }^{\mathrm{d}}$ & 4.669 & 0.870 & 4.382 & 3.912 & 8.613 \\
\hline CORFOR & Organizational openness of the legal form of incorporation $^{\mathrm{e}}$ & 0.415 & 0.746 & 0 & 0 & 2 \\
\hline EAST & Dummy for firms located in the eastern region of Russia & 0.482 & 0.500 & 0 & 0 & 1 \\
\hline EXPSHA & Share of exports in total sales ${ }^{\mathrm{f}}$ & 0.376 & 1.092 & 0 & 0 & 5 \\
\hline EXTAUD & Level of independence and expertise of contracted external auditor ${ }^{g}$ & 1.221 & 0.900 & 1 & 0 & 4 \\
\hline EXTAUDFIR & Dummy for firms executing external audit & 0.439 & 0.497 & 0 & 0 & 1 \\
\hline FOROWN & Dummy for foreign-owned companies & 0.044 & 0.205 & 0 & 0 & 1 \\
\hline GROFIR & Business group affiliation dummy & 0.216 & 0.412 & 0 & 0 & 1 \\
\hline$I N D D I R$ & Proportion of independent directors ${ }^{\text {a }}$ & 0.083 & 0.230 & 0.000 & 0.000 & 1.000 \\
\hline MANSHA & Large managerial shareholder dummy & 0.508 & 0.500 & 1 & 0 & 1 \\
\hline NUMAUD & Total number of audit committee members (corporate auditors) & 3.713 & 2.010 & 3 & 1 & 15 \\
\hline$N U M D I R$ & Total number of board directors & 4.844 & 2.275 & 5 & 1 & 15 \\
\hline OWNOUT & Combined ownership share of institutional and foreign investors ${ }^{\mathrm{h}}$ & 0.842 & 1.737 & 0 & 0 & 5 \\
\hline PRIJSC & Dummy for private (closed) joint-stock companies & 0.102 & 0.303 & 0 & 0 & 1 \\
\hline PRIVAT & Dummy for former state-owned or ex-municipal privatized companies & 0.105 & 0.307 & 0 & 0 & 1 \\
\hline PUBJSC & Dummy for public (open) joint-stock companies & 0.156 & 0.363 & 0 & 0 & 1 \\
\hline$R \& D$ & Research and development expenses ${ }^{\mathrm{i}}$ & 0.208 & 0.682 & 0 & 0 & 3 \\
\hline SPIOFF & Dummy for firms spun off from a state-owned/ex-municipal company or privatized company & 0.053 & 0.223 & 0 & 0 & 1 \\
\hline STAOWN & Dummy for state-owned and municipal companies & 0.101 & 0.302 & 0 & 0 & 1 \\
\hline$U R B A N$ & Dummy for firms located in urban areas & 0.790 & 0.408 & 1 & 0 & 1 \\
\hline
\end{tabular}

Notes:

${ }^{\mathrm{a}}$ Share of specific board directors/corporate auditors of total members that takes a value from 0.00 to 1.00

${ }^{\mathrm{D}} 7$-point scale ordinal variable that denotes 0: Firms did not use any bank credits during the period from 2010 to 2014; 1: Firms used bank credits, and their average lending period was less than months; 2: Firms used bank credits, and their average lending period ranged from 3 months to less than 6 months; 3 : Firms used bank credits, and their average lending period ranged from 6 months to

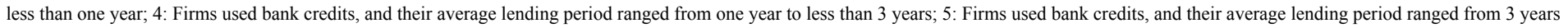
to less than 5 years; 6 : Firms used bank credits, and thier lending period was more than 5 years.

${ }^{\mathrm{c}}$ 3-point scale ordinal variable that denotes 0: Firms elect an inside board chairman; 1: Firms elect a quasi-inside board chairman; 2: Firms elect an outside board chairman.

${ }^{\mathrm{d}}$ Natural logarithm is used in estimation.

e 3-point scale ordinal variable that denotes 0: Limited liability companies; 1: Private (closed) joint-stock companies; 2: Public (open) joint-stock companies

${ }^{\mathrm{f}} 6$-point scale ordinal veriable that denotes 0 : The share of exports to total sales is $0 \%$; 1 : The share of exports to total sales is $10 \%$ or less; 2 : The share of exports to total sales ranges between 10.1 and $25.0 \% ; 3$ : The share of exports to total sales ranges between 25.1 and $50.0 \% ; 4$ : The share of exports to total sales ranges between 50.1 and $75.0 \% ; 5$ : The share of exports to total sales is more than ${ }^{\mathrm{g}} 5$-point scale ordinal variable that denotes: 0 : Firms contract with a local certified individual auditor; 1 : Firms contract with an indigenous audit firm; 2 : Firms contract with a regional audit firm with a local branch network; 3: Firms contract with a national audit firm with a branch network across federation; 4: Firms contract with an international audit firm.

${ }^{\mathrm{h}}$ 6-point scale ordinal variable that denotes 0 : Ownership share is $0 \% ; 1$ : Ownership share is $10.0 \%$ or less; 2 : Ownership share ranges between 10.1 and $25.0 \%$; 3 : Ownership share ranges between 25.1 and $50.0 \%$; 4 : Ownership share ranges between 50.1 and $75.0 \%$; : Ownership share ranges between 75.1 and $100.0 \%$.

${ }^{\mathrm{i}} 4$-point scale ordinal variable that denotes 0 : No R\&D expenses have been incurred during the period from 2010 to 2014; 1: A decreasing trend in R\&D expenses has been shown during the period from 2010 to 2014; 2: R\&D expenses have been mostly stable during the period from 2010 to 2014, 3: An increasing trend in R\&D expenses has been shown during the period from 2010 to 2014 . Source: ERINA Enterprise Survey 
Table 10. Estimation results of corporate board models

\begin{tabular}{|c|c|c|c|c|c|c|c|c|c|}
\hline Model & {$[1]$} & {$[2]$} & $\begin{array}{l}3] \\
\end{array}$ & {$[\overline{[4]}$} & [5] & 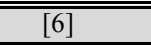 & $\begin{array}{l}\text { [7] } \\
\end{array}$ & $\begin{array}{l}{[8]} \\
\end{array}$ & {$[9]$} \\
\hline Estimator & Probit & Poisson & Heckman & Tobit & Heckman & Tobit & Heckman & Ordered probit & Heckman \\
\hline Dependent variable & $B O D F I R$ & NUMDIR & NUMDIR ${ }^{\mathrm{a}}$ & $B O A C O M$ & BOACOM & INDDIR & INDDIR & BOALEA & $B O A L E A^{\text {a }}$ \\
\hline EAST & $\begin{array}{l}-0.267^{* *} \\
(0.12)\end{array}$ & $\begin{array}{l}0.095{ }^{*} \\
(0.06)\end{array}$ & $\begin{array}{c}0.070 \\
(0.06)\end{array}$ & $\begin{array}{l}0.036 \\
(0.12)\end{array}$ & $\begin{array}{r}0.029 \\
(0.07)\end{array}$ & $\begin{array}{l}-0.970^{* * *} \\
(0.29)\end{array}$ & $\begin{array}{l}-0.085{ }^{*} \\
(0.05)\end{array}$ & $\begin{array}{c}-0.099 \\
(0.25)\end{array}$ & $\begin{array}{c}-0.197 \\
(0.16)\end{array}$ \\
\hline OWNOUT & $\begin{array}{l}0.042 \\
(0.04)\end{array}$ & $\begin{array}{l}0.006 \\
(0.01)\end{array}$ & $\begin{array}{r}-0.001 \\
(0.03)\end{array}$ & $\begin{array}{l}0.031 \\
(0.03)\end{array}$ & $\begin{array}{l}0.004 \\
(0.02)\end{array}$ & $\begin{array}{r}0.080 \\
(0.07)\end{array}$ & $\begin{array}{l}0.025 \\
(0.03)\end{array}$ & $\begin{array}{l}0.068 \\
(0.08)\end{array}$ & $\begin{array}{l}0.006 \\
(0.06)\end{array}$ \\
\hline STAOWN & $\begin{array}{l}0.017 \\
(0.23)\end{array}$ & $\begin{array}{l}0.102 \\
(0.07)\end{array}$ & $\begin{array}{l}0.066 \\
(0.11)\end{array}$ & $\begin{array}{l}0.090 \\
(0.14)\end{array}$ & $\begin{array}{l}0.020 \\
(0.13)\end{array}$ & $\begin{array}{l}0.055 \\
(0.28)\end{array}$ & $\begin{array}{l}0.036 \\
(0.15)\end{array}$ & $\begin{array}{r}-0.200 \\
(0.38)\end{array}$ & $\begin{array}{l}0.025 \\
(0.35)\end{array}$ \\
\hline FOROWN & $\begin{array}{l}0.056 \\
(0.30)\end{array}$ & $\begin{array}{l}0.071 \\
(0.09)\end{array}$ & $\begin{array}{l}0.098 \\
(0.19)\end{array}$ & $\begin{array}{c}0.185 \\
(0.20)\end{array}$ & $\begin{array}{r}0.132 \\
(0.15)\end{array}$ & $\begin{array}{l}-0.922 \\
(0.66)\end{array}$ & $\begin{array}{r}-0.034 \\
(0.21)\end{array}$ & $\begin{array}{l}-0.611 \\
(0.52)\end{array}$ & $\begin{array}{l}-0.204 \\
(0.44)\end{array}$ \\
\hline MANSHA & $\begin{array}{l}0.229^{*} \\
(0.12)\end{array}$ & $\begin{array}{l}-0.056 \\
(0.05)\end{array}$ & $\begin{array}{r}-0.123 \\
(0.10)\end{array}$ & $\begin{array}{l}-0.658^{* * *} \\
(0.11)\end{array}$ & $\begin{array}{l}-0.395^{* * *} \\
(0.11)\end{array}$ & $\begin{array}{l}-0.603^{* *} \\
(0.25)\end{array}$ & $\begin{array}{r}0.039 \\
(0.09)\end{array}$ & $\begin{array}{l}-0.965^{\text {*** }} \\
(0.26)\end{array}$ & $\begin{array}{r}-0.149 \\
(0.27)\end{array}$ \\
\hline GROFIR & $\begin{array}{l}0.320^{* *} \\
(0.15)\end{array}$ & $\begin{array}{l}0.047 \\
(0.06)\end{array}$ & $\begin{array}{l}0.015 \\
(0.11)\end{array}$ & $\begin{array}{l}0.188 \\
(0.12)\end{array}$ & $\begin{array}{l}0.009 \\
(0.12)\end{array}$ & $\begin{array}{c}-0.095 \\
(0.21)\end{array}$ & $\begin{array}{l}0.183 \\
(0.12)\end{array}$ & $\begin{array}{l}0.382 \\
(0.24)\end{array}$ & $\begin{array}{l}0.046 \\
(0.23)\end{array}$ \\
\hline PUBJSC & & $\begin{array}{l}0.243^{* * *} \\
(0.09)\end{array}$ & $\begin{array}{l}0.216^{* *} \\
(0.10)\end{array}$ & $\begin{array}{l}-0.277 \\
(0.19)\end{array}$ & $\begin{array}{l}-0.148^{* *} \\
(0.07)\end{array}$ & $\begin{array}{l}-1.657^{* * *} \\
(0.55)\end{array}$ & $\begin{array}{r}-0.071 \\
(0.04)\end{array}$ & $\begin{array}{r}-0.615 \\
(0.45)\end{array}$ & $\begin{array}{r}-0.279 \\
(0.35)\end{array}$ \\
\hline PRIJSC & & $\begin{array}{l}0.278^{* * *} \\
(0.09)\end{array}$ & $\begin{array}{l}0.256^{* * *} \\
(0.09)\end{array}$ & $\begin{array}{l}0.063 \\
(0.16)\end{array}$ & $\begin{array}{l}0.004 \\
(0.10)\end{array}$ & $\begin{array}{l}-1.285^{\text {*** }} \\
(0.49)\end{array}$ & $\begin{array}{r}-0.034 \\
(0.04)\end{array}$ & $\begin{array}{r}-0.258 \\
(0.40)\end{array}$ & $\begin{array}{r}-0.203 \\
(0.23)\end{array}$ \\
\hline PRIVAT & $\begin{array}{l}0.577^{* * *} \\
(0.20)\end{array}$ & $\begin{array}{c}0.034 \\
(0.07)\end{array}$ & $\begin{array}{r}-0.031 \\
(0.18)\end{array}$ & $\begin{array}{l}0.127 \\
(0.16)\end{array}$ & $\begin{array}{r}-0.084 \\
(0.20)\end{array}$ & $\begin{array}{l}1.163^{* * *} \\
(0.45)\end{array}$ & $\begin{array}{l}0.348 \\
(0.21)\end{array}$ & $\begin{array}{l}0.005 \\
(0.44)\end{array}$ & $\begin{array}{l}0.495 \\
(0.68)\end{array}$ \\
\hline SPIOFF & $\begin{array}{l}0.857^{* * *} \\
(0.27)\end{array}$ & $\begin{array}{l}0.115 \\
(0.09)\end{array}$ & $\begin{array}{c}-0.020 \\
(0.26)\end{array}$ & $\begin{array}{l}0.193 \\
(0.18)\end{array}$ & $\begin{array}{r}-0.052 \\
(0.25)\end{array}$ & $\begin{array}{l}2.1511^{* * *} \\
(0.51)\end{array}$ & $\begin{array}{l}0.577{ }^{*} \\
(0.32)\end{array}$ & $\begin{array}{l}-0.227 \\
(0.48)\end{array}$ & $\begin{array}{l}0.248 \\
(0.58)\end{array}$ \\
\hline$U R B A N$ & $\begin{array}{l}-0.386^{* *} \\
(0.15)\end{array}$ & $\begin{array}{l}-0.037 \\
(0.06)\end{array}$ & $\begin{array}{l}0.030 \\
(0.19)\end{array}$ & $\begin{array}{l}0.144 \\
(0.11)\end{array}$ & $\begin{array}{l}0.202 \\
(0.16)\end{array}$ & $\begin{array}{l}0.000 \\
(0.30)\end{array}$ & $\begin{array}{l}-0.266 \\
(0.26)\end{array}$ & $\begin{array}{l}0.717^{\text {** }} \\
(0.32)\end{array}$ & $\begin{array}{r}-0.008 \\
(0.31)\end{array}$ \\
\hline COMSIZ & $\begin{array}{l}0.404^{* * *} \\
(0.08)^{*}\end{array}$ & $\begin{array}{l}0.112^{* * *} \\
(0.03)\end{array}$ & $\begin{array}{l}0.059 \\
(0.14)\end{array}$ & $\begin{array}{l}0.134^{*} \\
(0.07)\end{array}$ & $\begin{array}{r}-0.015 \\
(0.12)\end{array}$ & $\begin{array}{l}0.318^{* *} \\
(0.14)\end{array}$ & $\begin{array}{c}0.217 \\
(0.14)\end{array}$ & $\begin{array}{l}0.139 \\
(0.14)\end{array}$ & $\begin{array}{c}0.060 \\
(0.33)\end{array}$ \\
\hline EXPSHA & & $\begin{array}{l}0.029 \\
(0.02)\end{array}$ & $\begin{array}{l}0.018 \\
(0.03)\end{array}$ & $\begin{array}{l}-0.042 \\
(0.05)\end{array}$ & $\begin{array}{l}-0.021 \\
(0.02)\end{array}$ & $\begin{array}{l}0.128^{*} \\
(0.08)\end{array}$ & $\begin{array}{l}-0.001 \\
(0.01)\end{array}$ & $\begin{array}{l}-0.151 \\
(0.10)\end{array}$ & $\begin{array}{l}0.026 \\
(0.12)\end{array}$ \\
\hline$B A N C R E$ & & $\begin{array}{r}-0.011 \\
(0.01)\end{array}$ & $\begin{array}{c}-0.008 \\
(0.01)\end{array}$ & $\begin{array}{r}-0.035 \\
(0.02)\end{array}$ & $\begin{array}{l}-0.021 \\
(0.01)\end{array}$ & $\begin{array}{l}-0.205^{* * *} \\
(0.06)\end{array}$ & $\begin{array}{l}-0.022^{* * *} \\
(0.01)\end{array}$ & $\begin{array}{l}-0.193^{* * *} \\
(0.05)\end{array}$ & $\begin{array}{l}-0.015 \\
(0.03)\end{array}$ \\
\hline$R \& D$ & & $\begin{array}{l}0.132^{* * *} \\
(0.02)\end{array}$ & $\begin{array}{l}0.134^{* * *} \\
(0.04)\end{array}$ & $\begin{array}{l}0.056 \\
(0.06)\end{array}$ & $\begin{array}{l}0.035 \\
(0.03)\end{array}$ & $\begin{array}{l}0.020 \\
(0.17)\end{array}$ & $\begin{array}{l}-0.001 \\
(0.02)\end{array}$ & $\begin{array}{l}0.248^{*} \\
(0.13)\end{array}$ & $\begin{array}{r}-0.037 \\
(0.10)\end{array}$ \\
\hline Const. & $\begin{array}{l}-2.483^{* * *} \\
(0.41)\end{array}$ & $\begin{array}{l}0.690^{* * *} \\
(0.14)\end{array}$ & $\begin{array}{l}1.310 \\
(1.26)\end{array}$ & $\begin{array}{r}-0.078 \\
(0.37)\end{array}$ & $\begin{array}{l}1.084 \\
(1.15)\end{array}$ & $\begin{array}{l}-1.762^{* * *} \\
(0.67)\end{array}$ & $\begin{array}{r}-1.897 \\
(1.35)\end{array}$ & & $\begin{array}{l}0.157 \\
(3.18)\end{array}$ \\
\hline Inverse Mills ratio & & & $\begin{array}{r}-0.310 \\
(0.50)\end{array}$ & & $\begin{array}{r}-0.396 \\
(0.48)\end{array}$ & & $\begin{array}{r}0.835 \\
(0.61)\end{array}$ & & $\begin{array}{l}0.258 \\
(0.90)\end{array}$ \\
\hline Industry dummies & Yes & Yes & Yes & Yes & Yes & Yes & Yes & Yes & Yes \\
\hline $\mathrm{N}$ & 647 & 187 & 647 & 187 & 642 & 187 & 642 & 174 & 520 \\
\hline Uncensored $\mathrm{N}$ & - & - & 187 & - & 187 & - & 187 & - & 65 \\
\hline Pseudo $\mathrm{R}^{2}$ & 0.17 & 0.12 & - & 0.24 & - & 0.32 & - & 0.21 & - \\
\hline$F$ - test/Wald test $\left(\chi^{2}\right)^{\mathrm{b}}$ & $114.02^{* * *}$ & $563.55^{* * *}$ & $118.14^{* * *}$ & $3.00^{* * *}$ & $231.87^{* * *}$ & $3.05^{* * *}$ & $49.74^{* * *}$ & $442.44^{* * *}$ & $48.80^{* * *}$ \\
\hline
\end{tabular}

Notes:

${ }^{\text {a }}$ Natural logarithm is used in estimation

${ }^{\mathrm{b}}$ Null hypothesis: All coefficients are zero.

Robust standard error in parentheses. In the Heckman models, the standard error is estimated by using the bootstrapping method. ***: significant at the $1 \%$ level, $* *$ : significant at the $5 \%$ level, *: significant at the $10 \%$ level

Source: Author's estimation. See Table 8 for the definition and descriptive statistics of the variables used in estimation. 
Table 11. Estimation results of audit system models

\begin{tabular}{|c|c|c|c|c|c|c|c|c|c|c|}
\hline Model & [1] & {$[2]$} & [3] & {$[4]$} & {$[5]$} & {$[6]$} & {$[7]$} & {$[8]$} & [9] & {$[10]$} \\
\hline Estimator & Probit & Poisson & Heckman & Tobit & Heckman & Tobit & Heckman & Probit & Ordered probit & Heckman \\
\hline Dependent variable & $A U D F I R$ & NUMAUD & $N_{U M A U D}{ }^{\text {a }}$ & $A U D C O M$ & $A U D C O M$ & $A U D E X P$ & $A U D E X P$ & EXTAUDFIR & EXTAUD & EXTAUD ${ }^{\text {a }}$ \\
\hline EAST & $\begin{array}{l}-0.360^{* * *} \\
(0.12)\end{array}$ & $\begin{array}{r}-0.147 \\
(0.12)\end{array}$ & $\begin{array}{l}-0.111 \\
(0.15)\end{array}$ & $\begin{array}{c}-0.039 \\
(0.21)\end{array}$ & $\begin{array}{l}0.010 \\
(0.08)\end{array}$ & $\begin{array}{l}-0.574^{* *} \\
(0.27)\end{array}$ & $\begin{array}{l}-0.057 \\
(0.07)\end{array}$ & $\begin{array}{c}-0.263 \text { ** } \\
(0.12)\end{array}$ & $\begin{array}{l}0.613 \\
(0.32)\end{array}$ & $\begin{array}{l}0.200 \\
(0.13)\end{array}$ \\
\hline OWNOUT & $\begin{array}{l}0.021 \\
(0.04)\end{array}$ & & & & & & & $\begin{array}{l}0.038 \\
(0.04)\end{array}$ & & \\
\hline$B O A C O M$ & & $\begin{array}{r}-0.032 \\
(0.16)\end{array}$ & $\begin{array}{l}-0.066 \\
(0.19)\end{array}$ & $\begin{array}{l}2.172^{* * *} \\
(0.36)\end{array}$ & $\begin{array}{l}0.795^{* * *} \\
(0.13)\end{array}$ & $\begin{array}{l}1.176^{* * *} \\
(0.41)\end{array}$ & $\begin{array}{l}0.187^{* *} \\
(0.09)\end{array}$ & & $\begin{array}{l}0.831^{* *} \\
(0.37)\end{array}$ & $\begin{array}{l}0.040 \\
(0.19)\end{array}$ \\
\hline STAOWN & $\begin{array}{l}0.505^{* *} \\
(0.24)\end{array}$ & $\begin{array}{l}0.304^{* * *} \\
(0.10)\end{array}$ & $\begin{array}{l}0.429^{* *} \\
(0.17)\end{array}$ & $\begin{array}{l}0.227 \\
(0.15)\end{array}$ & $\begin{array}{l}0.003 \\
(0.12)\end{array}$ & $\begin{array}{c}0.055 \\
(0.21)\end{array}$ & $\begin{array}{l}-0.011 \\
(0.09)\end{array}$ & $\begin{array}{l}-0.236 \\
(0.23)\end{array}$ & $\begin{array}{l}-0.195 \\
(0.32)\end{array}$ & $\begin{array}{r}-0.152 \\
(0.24)\end{array}$ \\
\hline FOROWN & $\begin{array}{l}-0.397 \\
(0.32)\end{array}$ & $\begin{array}{l}-0.159 \\
(0.12)\end{array}$ & $\begin{array}{r}-0.243 \\
(0.27)\end{array}$ & $\begin{array}{l}0.485 \\
(0.37)\end{array}$ & $\begin{array}{l}0.220 \\
(0.24)\end{array}$ & $\begin{array}{l}1.283^{* *} \\
(0.50)\end{array}$ & $\begin{array}{l}0.266 \\
(0.22)\end{array}$ & $\begin{array}{c}0.200 \\
(0.29)\end{array}$ & $\begin{array}{l}-0.023 \\
(0.48)\end{array}$ & $\begin{array}{l}0.272 \\
(0.30)\end{array}$ \\
\hline MANSHA & $\begin{array}{l}0.471^{* * *} \\
(0.12)\end{array}$ & & & & & & & $\begin{array}{r}-0.143 \\
(0.11)\end{array}$ & & \\
\hline GROFIR & $\begin{array}{c}0.172 \\
(0.15)\end{array}$ & $\begin{array}{l}0.103 \\
(0.08)\end{array}$ & $\begin{array}{l}0.106 \\
(0.12)\end{array}$ & $\begin{array}{r}-0.133 \\
(0.19)\end{array}$ & $\begin{array}{c}-0.050 \\
(0.10)\end{array}$ & $\begin{array}{l}0.395^{*} \\
(0.23)\end{array}$ & $\begin{array}{l}0.102 \\
(0.07)\end{array}$ & $\begin{array}{l}0.259^{*} \\
(0.14)\end{array}$ & $\begin{array}{c}0.331 \\
(0.26)\end{array}$ & $\begin{array}{c}0.142 \\
(0.21)\end{array}$ \\
\hline PUBJSC & & $\begin{array}{l}-0.227^{*} \\
(0.13)\end{array}$ & $\begin{array}{l}-0.151 \\
(0.17)\end{array}$ & $\begin{array}{l}0.830^{* * *} \\
(0.31)\end{array}$ & $\begin{array}{l}0.262^{* * *} \\
(0.10)\end{array}$ & $\begin{array}{l}0.958^{* *} \\
(0.40)\end{array}$ & $\begin{array}{l}0.243^{* * *} \\
(0.09)\end{array}$ & & $\begin{array}{l}0.277 \\
(0.45)\end{array}$ & $\begin{array}{l}0.166 \\
(0.20)\end{array}$ \\
\hline PRIJSC & & $\begin{array}{r}-0.024 \\
(0.14)\end{array}$ & $\begin{array}{l}-0.047 \\
(0.18)\end{array}$ & $\begin{array}{l}0.579^{* *} \\
(0.25)\end{array}$ & $\begin{array}{l}0.178^{*} \\
(0.09)\end{array}$ & $\begin{array}{l}0.538^{*} \\
(0.31)\end{array}$ & $\begin{array}{l}0.133^{*} \\
(0.07)\end{array}$ & & $\begin{array}{l}0.042 \\
(0.37)\end{array}$ & $\begin{array}{l}-0.027 \\
(0.15)\end{array}$ \\
\hline PRIVAT & $\begin{array}{l}0.693^{* * *} \\
(0.21)^{4}\end{array}$ & $\begin{array}{l}0.226^{*} \\
(0.12)\end{array}$ & $\begin{array}{l}0.405^{* *} \\
(0.19)\end{array}$ & $\begin{array}{r}-0.335 \\
(0.25)\end{array}$ & $\begin{array}{c}-0.201 \\
(0.16)\end{array}$ & $\begin{array}{r}-0.203 \\
(0.30)\end{array}$ & $\begin{array}{r}-0.050 \\
(0.10)\end{array}$ & $\begin{array}{l}0.4288^{* *} \\
(0.21)\end{array}$ & $\begin{array}{l}-0.247 \\
(0.33)\end{array}$ & $\begin{array}{l}0.041 \\
(0.29)\end{array}$ \\
\hline SPIOFF & $\begin{array}{l}0.482^{*} \\
(0.29)\end{array}$ & $\begin{array}{l}0.124 \\
(0.10)\end{array}$ & $\begin{array}{l}0.275 \\
(0.19)\end{array}$ & $\begin{array}{r}-0.348 \\
(0.30)\end{array}$ & $\begin{array}{r}-0.209 \\
(0.17)\end{array}$ & $\begin{array}{l}-0.688^{*} \\
(0.38)\end{array}$ & $\begin{array}{l}-0.094 \\
(0.13)\end{array}$ & $\begin{array}{l}0.100 \\
(0.26)\end{array}$ & $\begin{array}{r}-0.432 \\
(0.44)\end{array}$ & $\begin{array}{l}0.033 \\
(0.30)\end{array}$ \\
\hline URBAN & $\begin{array}{r}0.057 \\
(0.15)\end{array}$ & $\begin{array}{r}-0.177 \\
(0.11)\end{array}$ & $\begin{array}{l}-0.248{ }^{*} \\
(0.14)\end{array}$ & $\begin{array}{l}-0.620^{* * *} \\
(0.21)\end{array}$ & $\begin{array}{r}-0.143 \\
(0.11)\end{array}$ & $\begin{array}{l}-0.522^{* *} \\
(0.24)\end{array}$ & $\begin{array}{r}-0.090 \\
(0.08)\end{array}$ & $\begin{array}{l}-0.329^{* *} \\
(0.15)\end{array}$ & $\begin{array}{l}-0.395 \\
(0.31)\end{array}$ & $\begin{array}{r}-0.188 \\
(0.23)\end{array}$ \\
\hline COMSIZ & $\begin{array}{l}0.396^{* * *} \\
(0.09)\end{array}$ & $\begin{array}{l}0.064 \\
(0.05)\end{array}$ & $\begin{array}{l}0.091 \\
(0.12)\end{array}$ & $\begin{array}{l}-0.311^{* * *} \\
(0.11)\end{array}$ & $\begin{array}{r}-0.126 \\
(0.08)\end{array}$ & $\begin{array}{l}-0.326^{* *} \\
(0.16)\end{array}$ & $\begin{array}{r}-0.009 \\
(0.06)\end{array}$ & $\begin{array}{l}0.4400^{* * *} \\
(0.09)\end{array}$ & $\begin{array}{l}0.155 \\
(0.16)\end{array}$ & $\begin{array}{l}0.257^{*} \\
(0.15)\end{array}$ \\
\hline EXPSHA & & $\begin{array}{l}0.047 \\
(0.03)\end{array}$ & $\begin{array}{l}0.025 \\
(0.05)\end{array}$ & $\begin{array}{l}0.013 \\
(0.06)\end{array}$ & $\begin{array}{r}-0.004 \\
(0.03)\end{array}$ & $\begin{array}{l}0.2411^{* *} \\
(0.10)\end{array}$ & $\begin{array}{l}0.038^{*} \\
(0.02)\end{array}$ & & $\begin{array}{r}-0.052 \\
(0.13)\end{array}$ & $\begin{array}{l}0.087 \\
(0.06)\end{array}$ \\
\hline BANCRE & & $\begin{array}{r}-0.010 \\
(0.02)\end{array}$ & $\begin{array}{l}-0.004 \\
(0.03)\end{array}$ & $\begin{array}{l}0.072{ }^{*} \\
(0.04)\end{array}$ & $\begin{array}{l}0.022 \\
(0.02)\end{array}$ & $\begin{array}{l}0.198^{* * *} \\
(0.07)\end{array}$ & $\begin{array}{l}0.029^{*} \\
(0.02)\end{array}$ & & $\begin{array}{r}-0.039 \\
(0.06)\end{array}$ & $\begin{array}{l}0.021 \\
(0.02)\end{array}$ \\
\hline$R \& D$ & & $\begin{array}{l}0.034 \\
(0.05)\end{array}$ & $\begin{array}{l}0.038 \\
(0.06)\end{array}$ & $\begin{array}{l}0.190^{* *} \\
(0.10)\end{array}$ & $\begin{array}{l}0.074 \\
(0.05)\end{array}$ & $\begin{array}{l}0.124 \\
(0.11)\end{array}$ & $\begin{array}{l}0.044 \\
(0.04)\end{array}$ & & $\begin{array}{l}0.077 \\
(0.11)\end{array}$ & $\begin{array}{l}-0.082 \\
(0.06)\end{array}$ \\
\hline Const. & $\begin{array}{l}-2.271^{* * *} \\
(0.45)\end{array}$ & $\begin{array}{l}1.009^{* * *} \\
(0.26)\end{array}$ & $\begin{array}{l}0.521 \\
(0.89)\end{array}$ & $\begin{array}{l}0.600 \\
(0.49)\end{array}$ & $\begin{array}{l}0.745 \\
(0.66)\end{array}$ & $\begin{array}{l}-0.183 \\
(0.72)\end{array}$ & $\begin{array}{l}-0.139 \\
(0.53)\end{array}$ & $\begin{array}{l}-1.928^{* * *} \\
(0.42)\end{array}$ & & $\begin{array}{r}-1.689 \\
(1.33)\end{array}$ \\
\hline Inverse Mills ratio & & & $\begin{array}{r}0.246 \\
(0.33)\end{array}$ & & $\begin{array}{l}-0.116 \\
(0.23)\end{array}$ & & $\begin{array}{l}0.064 \\
(0.22)\end{array}$ & & & $\begin{array}{l}0.523 \\
(0.46)\end{array}$ \\
\hline Industry dummies & Yes & Yes & Yes & Yes & Yes & Yes & Yes & Yes & Yes & Yes \\
\hline $\mathrm{N}$ & 633 & 119 & 535 & 119 & 535 & 119 & 535 & 626 & 112 & 445 \\
\hline Uncensored N & - & - & 119 & - & 119 & - & 119 & - & - & 94 \\
\hline Adj. $R^{2} /$ Pseudo $R^{2}$ & 0.18 & 0.07 & - & 0.36 & - & 0.26 & - & 0.13 & 0.16 & - \\
\hline$F$ - test $/$ Wald test $\left(\chi^{2}\right)^{\mathrm{b}}$ & $98.63^{* * *}$ & $74.31^{* * *}$ & $47.07^{* * *}$ & $2.16^{* * *}$ & $446.46^{* * *}$ & 1.36 & $213.54^{* * *}$ & $88.19^{* * *}$ & $44.64^{* *}$ & $355.32^{* * *}$ \\
\hline
\end{tabular}

Notes:

${ }^{a}$ Natural logarithm is used in estimation.

${ }^{\mathrm{b}}$ Null hypothesis: All coefficients are zero.

Robust standard error in parentheses. In the Heckman models, the standard error is estimated by using the bootstrapping method. ***: significant at the $1 \%$ level, **: significant at the $5 \%$ level, *: significant at the $10 \%$ level

Source: Author's estimation. See Table 8 for the definition and descriptive statistics of the variables used in estimation. 
Appendix. Descriptive statistics of the variables used in regression analysis by region and results of univariate comparative analysis between the eastern and western regions of Russia

\begin{tabular}{|c|c|c|c|c|c|c|c|c|c|c|}
\hline \multirow{3}{*}{ Variable name } & \multicolumn{10}{|c|}{ Descriptive statistics } \\
\hline & \multicolumn{5}{|c|}{ Eastern region } & \multicolumn{5}{|c|}{ Western region } \\
\hline & $\begin{array}{c}\text { Mean/ } \\
\text { proportion }{ }^{\mathrm{a}}\end{array}$ & S.D. & Median ${ }^{b}$ & Min. & Max. & $\begin{array}{c}\text { Mean/ } \\
\text { proportion }\end{array}$ & S.D. & Median & Min. & Max. \\
\hline$A U D C O M$ & $0.451^{* * *}$ & 0.432 & 0.333 & 0.000 & 1.000 & 0.245 & 0.330 & 0.000 & 0.000 & 1.000 \\
\hline$A U D E X P$ & 0.148 & 0.290 & 0.000 & 0.000 & 1.000 & 0.106 & 0.234 & 0.000 & 0.000 & 1.000 \\
\hline$A U D F I R$ & $0.305^{\dagger}$ & 0.461 & $0^{\#}$ & 0 & 1 & 0.374 & 0.485 & 0 & 0 & 1 \\
\hline$B A N C R E$ & $2.576^{*}$ & 2.272 & $3^{\#}$ & 0 & 6 & 2.296 & 2.179 & 3 & 0 & 6 \\
\hline BOACOM & $0.486^{* *}$ & 0.406 & 0.500 \# & 0.000 & 1.000 & 0.365 & 0.364 & 0.333 & 0.000 & 1.000 \\
\hline BOALEA & 0.692 & 0.872 & 0 & 0 & 2 & 0.621 & 0.901 & 0 & 0 & 2 \\
\hline BODFIR & $0.251^{\dagger}$ & 0.434 & $0^{\text {\#\# }}$ & 0 & 1 & 0.318 & 0.466 & 0 & 0 & 1 \\
\hline COMSIZ & $4.749^{* *}$ & 0.940 & 4.443 & 3.912 & 8.517 & 4.595 & 0.792 & 4.317 & 3.912 & 8.613 \\
\hline CORFOR & 0.425 & 0.773 & 0 & 0 & 2 & 0.406 & 0.720 & 0 & 0 & 2 \\
\hline EAST & $1.000^{\dagger \dagger}$ & 0.000 & $11^{\# \# \#}$ & 1 & 1 & 0.000 & 0.000 & 0 & 0 & 0 \\
\hline EXPSHA & 0.393 & 1.175 & 0 & 0 & 5 & 0.360 & 1.011 & 0 & 0 & 5 \\
\hline EXTAUD & $1.450^{* * *}$ & 0.999 & 1 \#册 & 0 & 4 & 1.035 & 0.764 & 1 & 0 & 4 \\
\hline EXTAUDFIR & 0.420 & 0.494 & 0 & 0 & 1 & 0.456 & 0.499 & 0 & 0 & 1 \\
\hline FOROWN & $0.062{ }^{\dagger \dagger}$ & 0.241 & $0^{\# \#}$ & 0 & 1 & 0.029 & 0.168 & 0 & 0 & 1 \\
\hline GROFIR & $0.282^{\dagger \dagger}$ & 0.451 & 0 & 0 & 1 & 0.154 & 0.361 & 0 & 0 & 1 \\
\hline$I N D D I R$ & 0.067 & 0.219 & 0.000 & 0.000 & 1.000 & 0.095 & 0.238 & 0.000 & 0.000 & 1.000 \\
\hline MANSHA & 0.530 & 0.500 & 1 & 0 & 1 & 0.488 & 0.501 & 0 & 0 & 1 \\
\hline NUMAUD & 3.553 & 2.061 & 3 & 1 & 13 & 3.830 & 1.971 & 3 & 1 & 15 \\
\hline NUMDIR & $5.289^{* *}$ & 2.554 & $5^{\# \#}$ & 1 & 15 & 4.516 & 1.993 & 5 & 1 & 13 \\
\hline OWNOUT & $0.974^{*}$ & 1.888 & 0 & 0 & 5 & 0.732 & 1.594 & 0 & 0 & 5 \\
\hline PRIVAT & 0.089 & 0.286 & 0 & 0 & 1 & 0.120 & 0.325 & 0 & 0 & 1 \\
\hline PRIJSC & $0.073^{\dagger \dagger}$ & 0.260 & $0^{\# \# \#}$ & 0 & 1 & 0.130 & 0.337 & 0 & 0 & 1 \\
\hline PUBJSC & 0.176 & 0.381 & 0 & 0 & 1 & 0.138 & 0.345 & 0 & 0 & 1 \\
\hline$R \& D$ & 0.203 & 0.670 & 0 & 0 & 3 & 0.212 & 0.695 & 0 & 0 & 3 \\
\hline SPIOFF & $0.075^{\dagger \dagger}$ & 0.264 & 0 & 0 & 1 & 0.031 & 0.174 & 0 & 0 & 1 \\
\hline STAOWN & 0.083 & 0.276 & 0 & 0 & 1 & 0.117 & 0.322 & 0 & 0 & 1 \\
\hline URBAN & $0.880^{\dagger \dagger}$ & 0.326 & 1 \#\#\# & 0 & 1 & 0.706 & 0.456 & 1 & 0 & 1 \\
\hline
\end{tabular}

Notes:

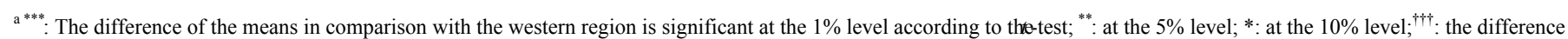
of the proportions in comparison with the western region is significant at the $1 \%$ level according to the test of proportions; $\dagger \dagger$ : at the $5 \%$ level; $\uparrow:$ at the $10 \%$ level.

b ${ }^{\prime \prime \#}$ : The difference in comparison with the western region is significant at the $1 \%$ level according to the Wilcoxon rank-sum test;: at the $5 \%$ level; ${ }^{\#}$ : at the $10 \%$ level. Source: Author's estimation. See Table 8 for the definition and descriptive statistics of the variables. 